\title{
Archaeological Exploration of Tappeh Hissar, Damghan Using Forward and Inverse Modeling of Ground- Penetrating Radar Data
}

\author{
Afsaneh Ahmadpour ${ }^{* 1}$, Abolghasem Kamkar-Rouhani ${ }^{2}$, Reza Ahmadi ${ }^{3}$ \\ ${ }^{1}$ M.S in the field of Geoelectric, Shahrood University of Technology, Shahrood. IRAN \\ ${ }^{2}$ Associate Professor, Faculty of Mining, Petroleum \& Geophysics Engineering Shahrood University of \\ Technology, Shahrood. IRAN \\ ${ }^{3}$ Assistance Professor, Faculty of Mining Engineering Arak University of Technology, Arak. IRAN
}

\begin{abstract}
Ground penetrating radar (GPR) method is a non-destructive geophysical method that is used to detect subsurface heterogeneities and also recognition of various shallow targets. In present research, forward and inverse modeling of GPR data applied for archaeological study has been made. The study area is Tappeh Hissar, Damghan, in which GPR data along several survey lines have been acquired using $250 \mathrm{MHz}$ shielded antenna for archaeological investigations. To achieve the goal, the real radar-gram of a survey line in the area has been obtained after applying different processing operations containing signal saturation correction and applying band-pass, auto-gain control and background re-moval filters on the GPR data using Reflexw software. Then, the synthetic radargram corresponding to the real radargram has been simulated using finite-different time domain (FDTD) method. After-ward inversion method with solution of an optimization problem was employed for validation of in-terpretation of GPR radargram in order to detect buried targets. The results of this research, that are based on the agreement between the radargram obtained from the real GPR data and the synthetic radargram corresponding to the real radargram, confirm the correctness of the interpretation of sub-surface archaeological investigations in the area, and thus, indicate the capability of application of GPR method for archaeological exploration.
\end{abstract}

Keywords: Archaeology, Tappeh Hissar, Ground penetrating radar (GPR), Forward modeling, Inverse modeling.

*Corresponding author: aahmadpour_geo@shahroodut.ac.ir 


\section{بررسى هاى باستانشناسى منطقه تِه حصار دامغان با استفاده از مدلسازى ييشرو و وارون دادههاى رادار نفوذى به زمين

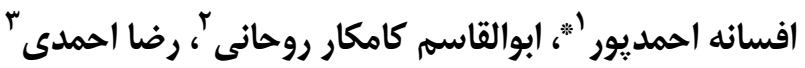 \\ 1 ا كارشناسى ارشد زئوالكتريك، دانشكاه صنعتى شاهرود

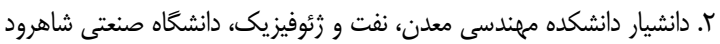 \\ ب. استاديار دانشكده مهندسى معدن، دانشخاه صنعتى اراك}

جكيده

روش رادار نفوذى به زمين (GPR) يك روش زئوفيزيكى غير مخرب است كه قادر به آشكارسازى انواع ناهمكنى هاى زيرسطحى و نيز

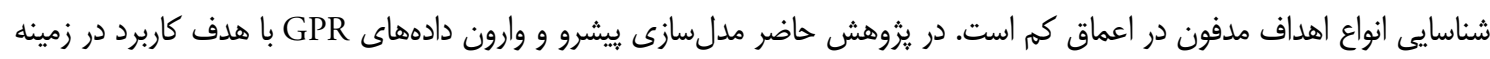

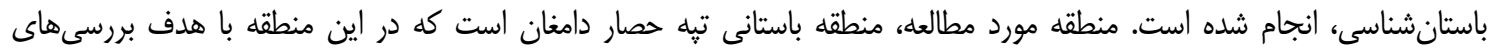

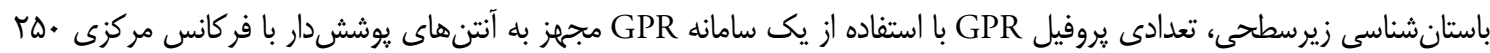

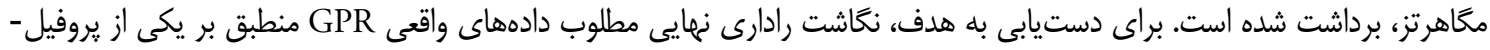

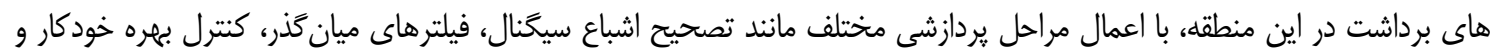

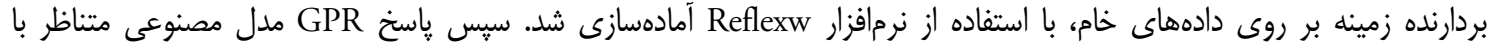

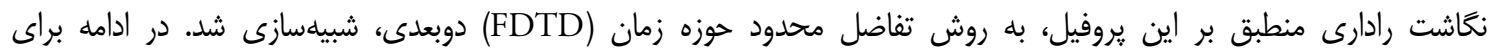

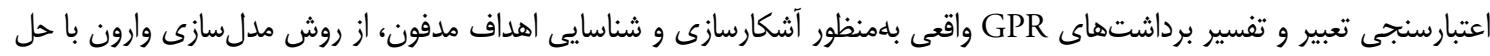

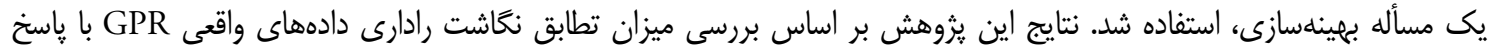

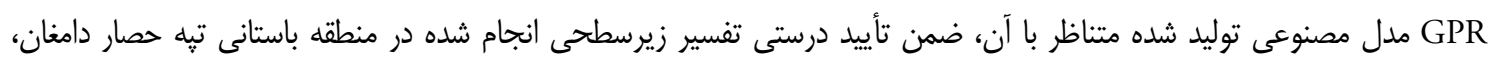

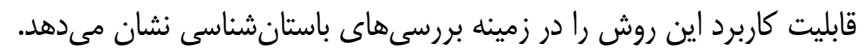

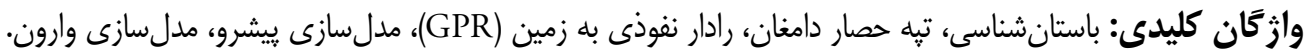

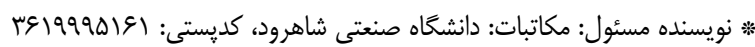

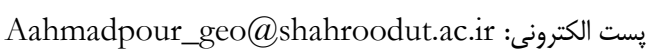
Cب حق نشر متعلق به نويسنده(كان) است و نويسنده تحت مجوز Creative Commons Attribution License به مجله اجازه مىدهد مقاله جاب شده را با ديخران به اشتراك بحذارد منوط بر اينكه حقوق مؤلف اثر حفظ و بونه به انتشار اوليه مقاله در اين مجله اشاره شود. 
بررسىهاى مختلف، سـبب اهميـت فزاينـده ايـن روش و توجه ويزه يزوهشكران به روشهاى مختلـف يـردازش و و مدلسازى دادهاى اين روش در دهه اخير شده است. وجود يك ديوار كه نسبت به محسيط دربر كيرنـدهاش

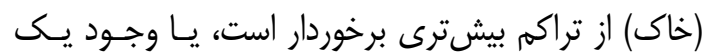

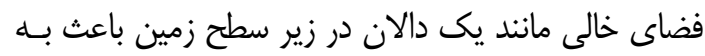

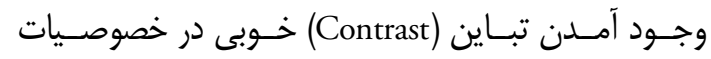

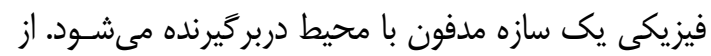
اين جهت محوطههاى باستانى و بلهور خاص سازهـاى

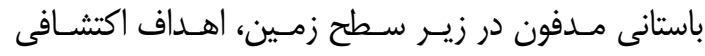

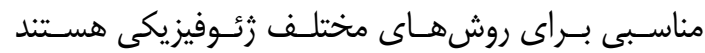

.(Arisoy et al., 2007; Conyers \& Goodman, 2004)

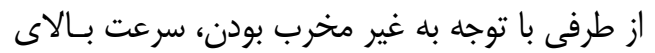

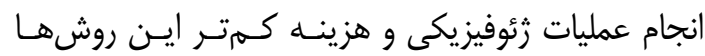
نسبت به كاوشهاى اكتشافى، به نظر مىرسد كه استفاده

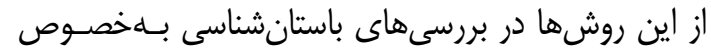
ييش از شروع به كار باستانشناسان، مىتواند كمك قابـل

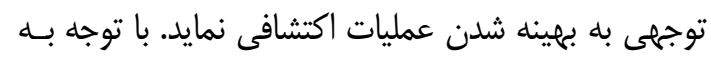
محدوديتهاى اين روش كاهى در مقاطع به دسـت آمــده

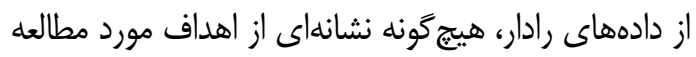

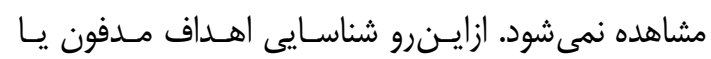

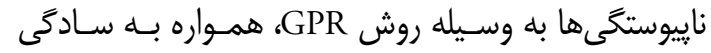

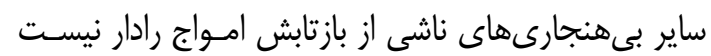

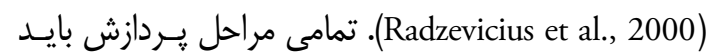
بجا و در حد نياز صورت بذيرد وگرّنه ممكن است يردازش به حدى مقطع دادههاى رادار را ساده نمايد كه مفسر دهار تصورى اشتباه در مورد شرايط واقعى حاكم در زمين شـود رادئ.

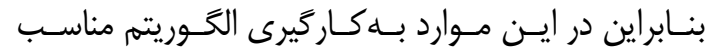

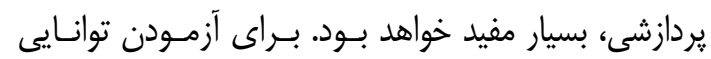

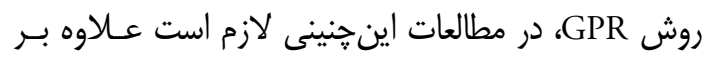

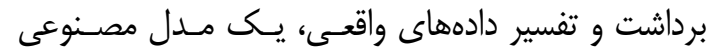

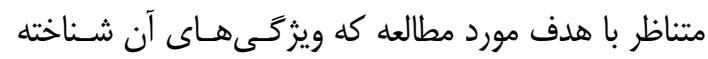

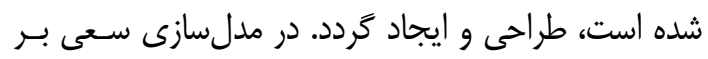
آن است تا از بازتاب امواج الكترومغناطيسى ارسال شده بـ به درديه

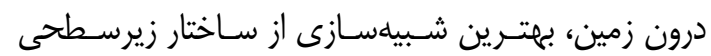

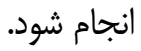

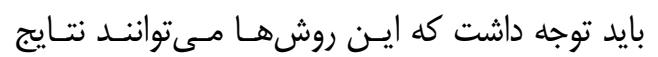

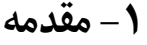

بررسىهـــاى باسـتان زئـوفيزيكى شـامل مجموعـهاى از

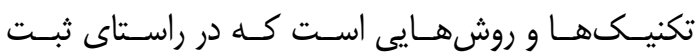

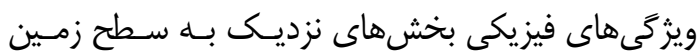

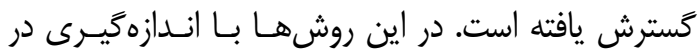
نقاطى بر روى سطح زمين مىتوان به بخشى از ويزَّى و تغييرات در شرايط فيزيكى زيرين زمين و تفـاوتهـايى نعاطي

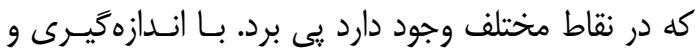
تعيين اين تفاوت در بخشهاى مختلف كه از آن با عنوان

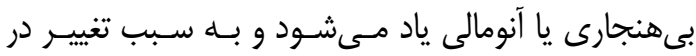

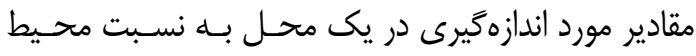

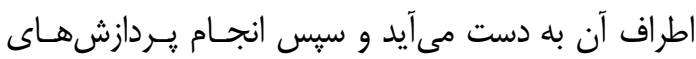

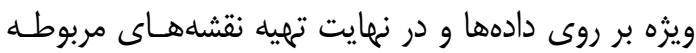

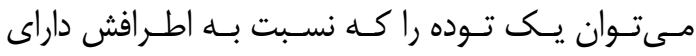

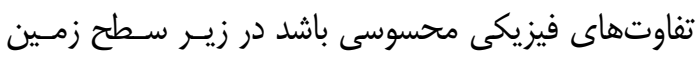

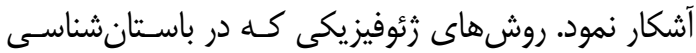

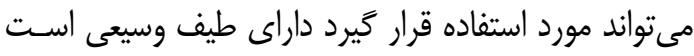

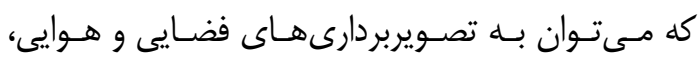

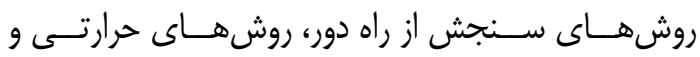
تصويربردارى با استفاده از يرتوهاى فروسـرخ، روشهـاى إى مغناطيس سنجى، الكتريكى، رادار زمينى، الكترومغناطيسى،

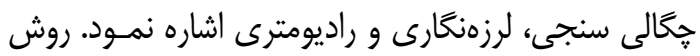

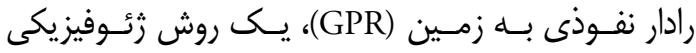

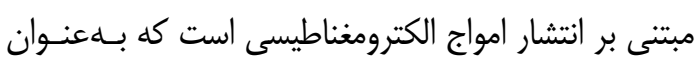

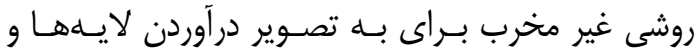
Daniels, 2004) ناهمخنىهاى زيرسطحى به كار مسىرون

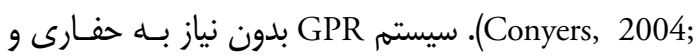

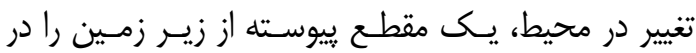
اختيار قرار مىدهد. روش GPR در برداشتها داراى جهيـار

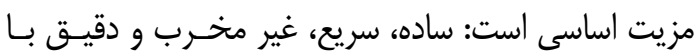
قدرت تفكيك زياد (Shafri et al., 2008). اين خصوصيات باعث شده است تا اين روش براى بررسى هاى كمهعمق،

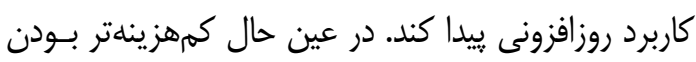

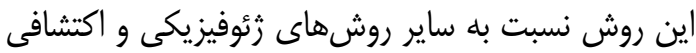
و نيز دارا بودن طيف وسيعى از كاربردها بلويـره در زمينـهـ

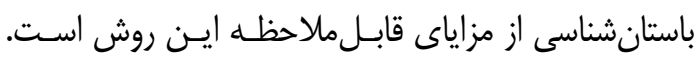
بنابراين موفقيـتآميـز بـودن ايـن روش و كـاربرد آن در

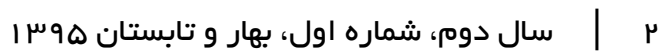


مدلسازى ييشرو و وارون دادههاى GPR با هدف بررسى

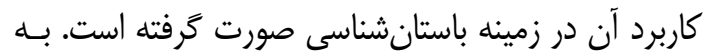

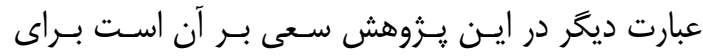
اعتبارسنجى تعبير و تفسـير برداشـتهـاى GPR و ايجـاد مدلى از زمين كه ياسخى مشابه دادههاى اندازهخيرى شده داشته باشد، از روش مدلسازى وارون استفاده شود.

\section{r- يشينه تحقيق}

روش رادار نفــوذى بـــه زمـين نيــز بــا فرسـتادن امـواج الكترومغناطيسى فر كانس بالا به زمين و اندازهذيرى زمان رفت و بركشت موج در گيرنده، شكل هندسى، ابعاد، عمق قرارگيرى اهداف زيرسطحى و موقعيت فصل مشـتركهــا را در اعماق كم مشخص مى كند و در نتيجه مسىتوانسد در

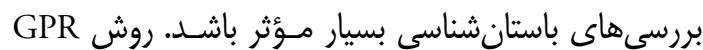

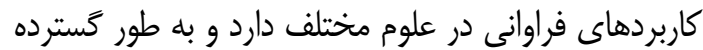
در به تصوير كشيدن اهداف زيرسطحى كهم عمـق مـورد

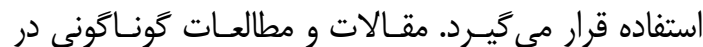
حوزه علوم زمينشناسى (Denis et al., 2009; Christie et (al., 2009;) Pauselli et al., 2010 Reynolds, 1997; Knight, 2001) (Hubbard \& Rubin, 2005; Lin et al., 2009)، مطالهـ Brandt et al., 2007; Hagg et al., 2013; ) يخجـال Negri et al., 2008; ( ) باستانشناسى)، (Singh et al., 2012 Grandjean et al., 2000; Gracia et al., 2000 Al-Nuaimy et ) اهداف مدفون شامل لوله، قنات و غيـره

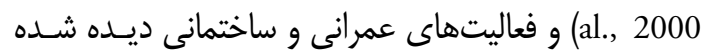
است. بيمايشهاى زئوفيزيكى در محوطههاى باستانى كه

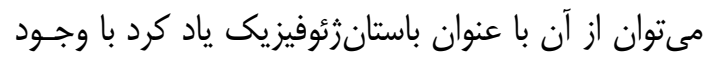
سابقه طولانى تنها در سالهاى اخير كَسترش يافتـه و بـا نتايج جشمخيرى همراه بـوده اسـت. در سـالهـاى اخيـر ييشرفتهاى جشمخير در دانش الكترونيـك و كـامييوتر

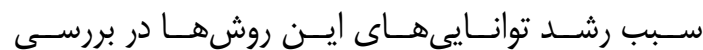
محوطههاى باستانى شده است. ييشــينه كـاربرد روشهــاى زئسوفيزيكى در باسـتان

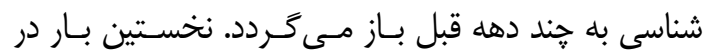

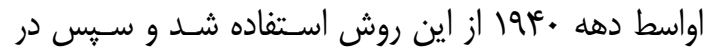

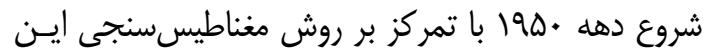
$\mu$ سال دوه، شماره اول، بهار و تابستان هوسـ
جامع و مفيدى براى تفسـير ابتـايى ياسـخهــاى GPR از

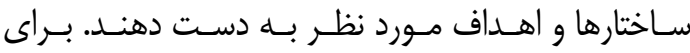

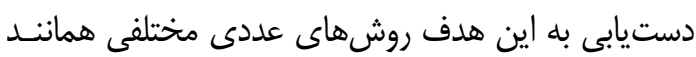

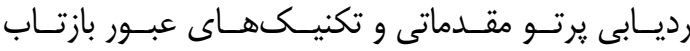

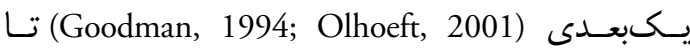
كَونهاى مختلف روش اخـتاف محسدود ( Bergmann et al., 1998; Giannopoulos, 2005; Teixeira et al., 1998)، تكنيـكهـاى حجـم محـدود، تبـديل Z و اجـزاء

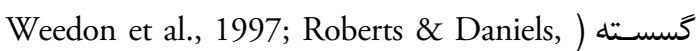
(1997; Bourgeois \& Smith, 1996

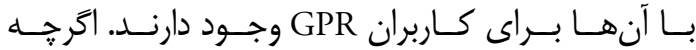
روششناسى آنها با يكديخر متفاوت است، در همه آنهـا انتشار و بازتاب امواج GPR به درون زمين، بر اساس رفتاس دئار

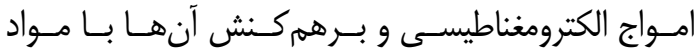
زيرسطحى، شبيهسازى مىشود (Jol, 2009).

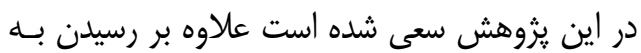
ديدى واضحتر از زير سطح و تفسيرى دقيقتر، كارايى اين روش در بررسىهاى باستانى در منطقه تبه حصار دامغـان

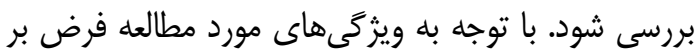
اين بود كه اگر بنايى در زير سطح مدفون باشده با توجه به

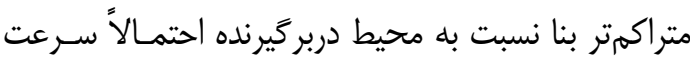

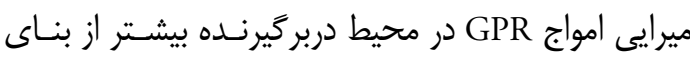

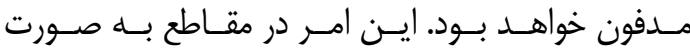

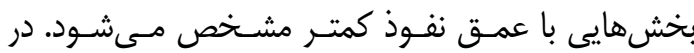

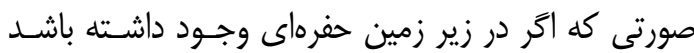

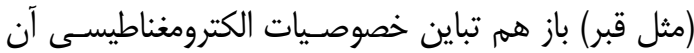

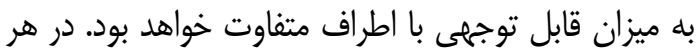

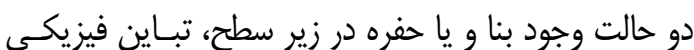
مربوطه لازم بين هدف مدفون و مـواد محصـور كنندهاش

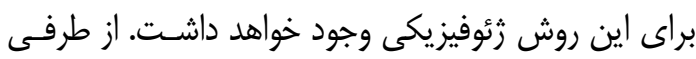
با در نظر كرفتن موفقيت روشهاى زئوفيزيكى در تعيـين

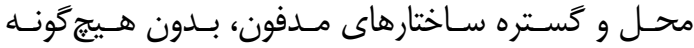

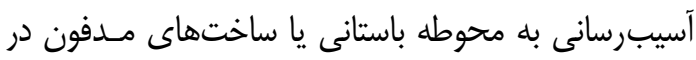

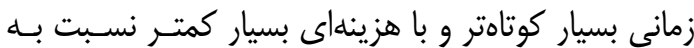

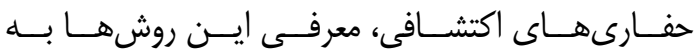

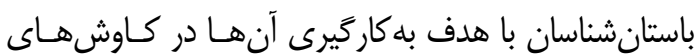

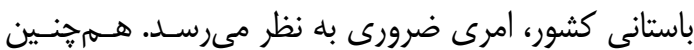


روشهاى الكتريكى و GPR مىتوان به محوطه باستتانى

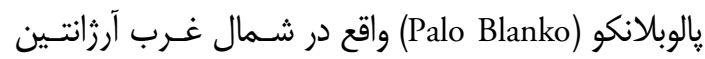
و بررسىهاى مغناطيس سنجى و و (Martino et al., 2006)

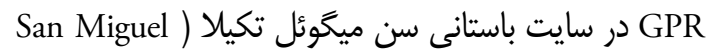
Arciniega-Ceballos et (Tocuila

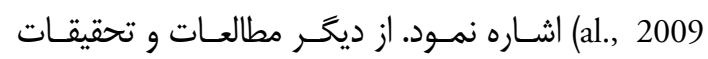

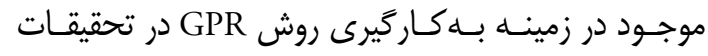

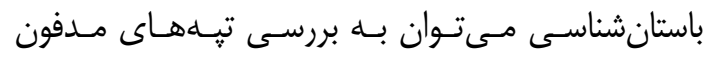

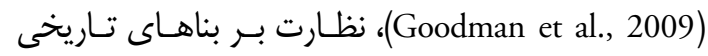

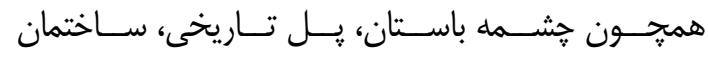
و (Sambuelli et al., 2009; Solla et al., 2011)

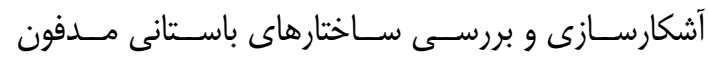
(Muztaza, 2012)

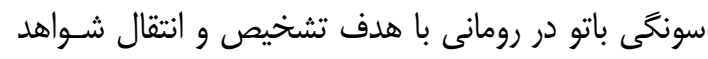

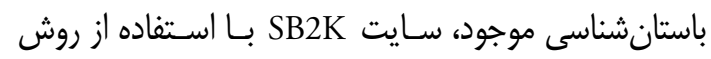

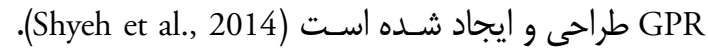

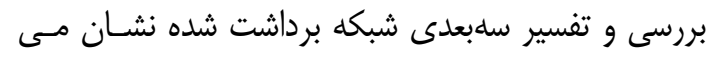

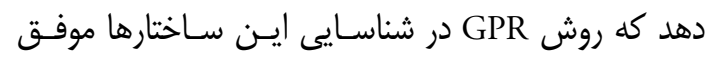

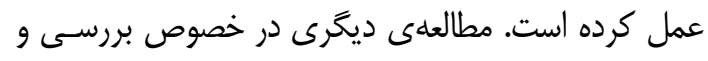

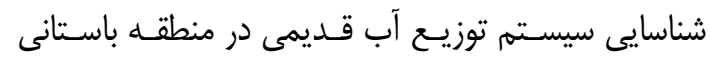

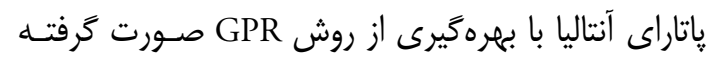

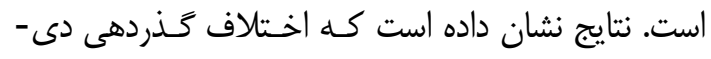

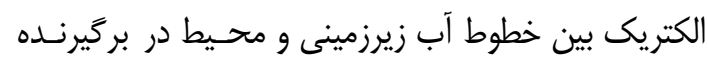

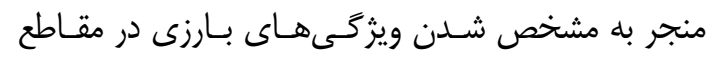

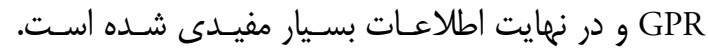

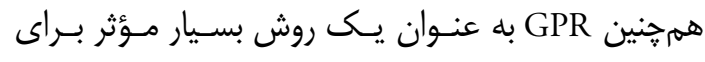

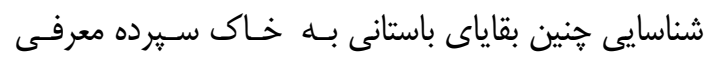

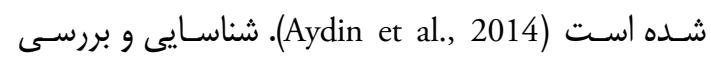

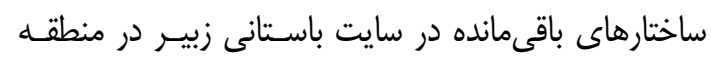

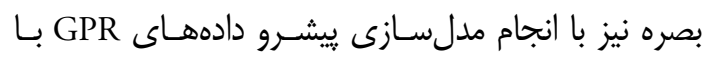
استفاده از روش تفاضل محدود (Finite difference) انجام بنام شده است. نتايج نشاندهندهى متفاوت بودن مدل ساضل مازى از باز تاب امواج با ساختار مدفون شده و تعامل يبيجيده امـواج

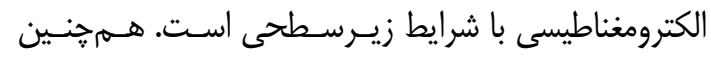

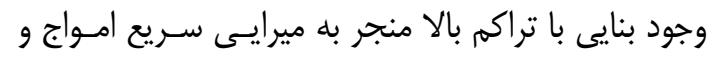
كاهش عمق نفوذ امواج مىشود (Alaamer, 2015).

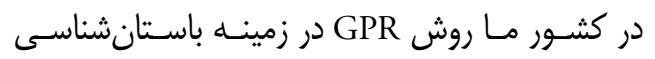

فعاليتها به انجام رسيد. استفاده از روشهاى لرزمنغارى با

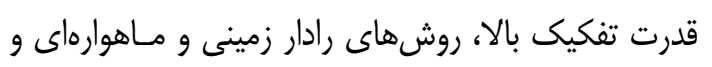

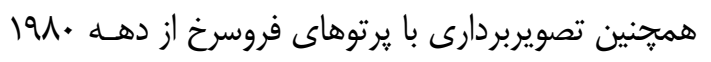

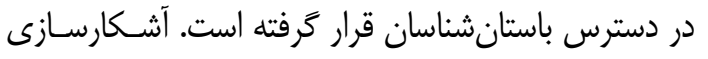
ساختار معمارى مدفون در خاك، مشتخص كـردن يـانلان

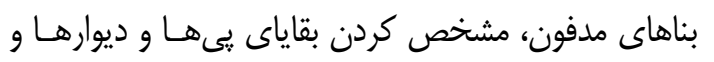

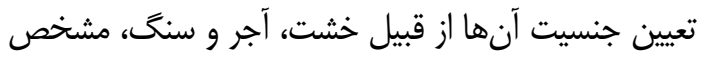

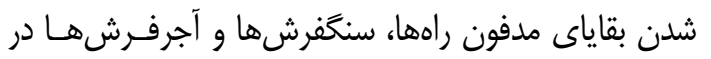

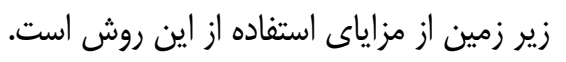

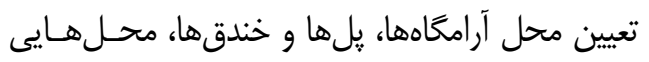

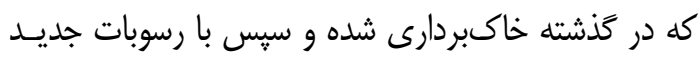

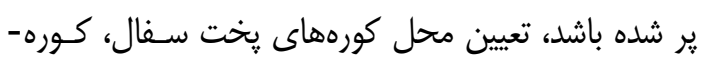
هاى ذوب فلز، محل خاكهاى سوخته و خاكستر و تعيين

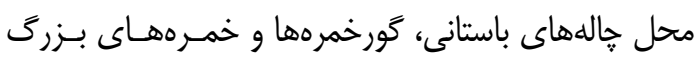

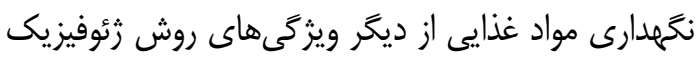

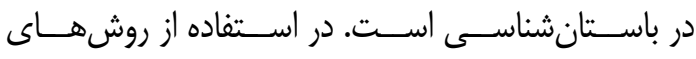

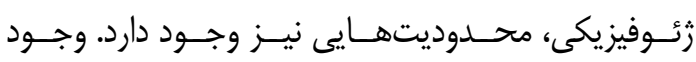

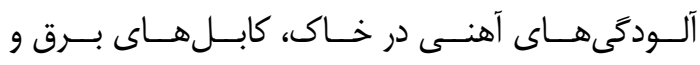
فنس كشىهاى موجود در منطقه مانع استفاده از اين روش دائه

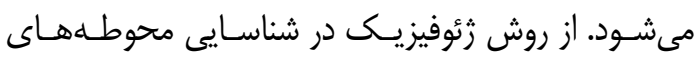

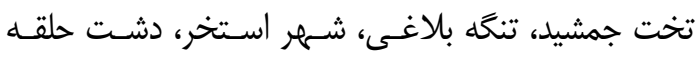

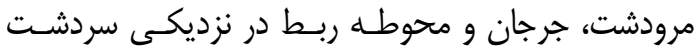

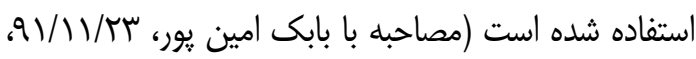
كزارش ميراث آريا).

ايده استفاده از امواج الكترومغنـاطيس فر كـانس بـالا

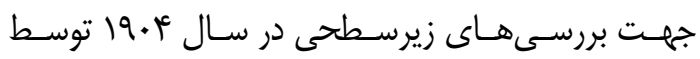
هولسمير محقق آلمانى ارائه شده است (Parasnis, 1997).

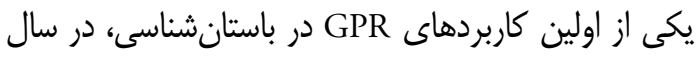

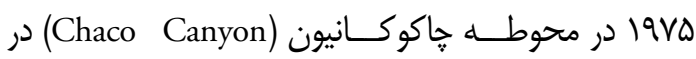
نيومكزيكوى آمريكـا انجـام شـــ (Vickers et al., 1976). هدف از اين مطالعه اكتشاف محل ديوارههاى احتمـالى در

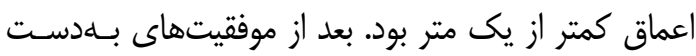

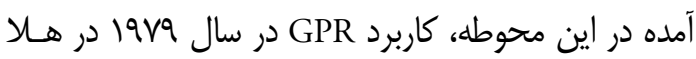

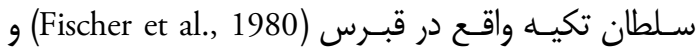
Sheets et al., ) محوطه باستانى سِـرن كشـور السـالوادور

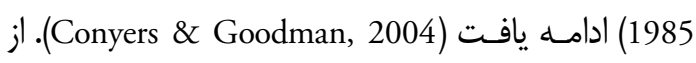

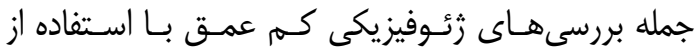

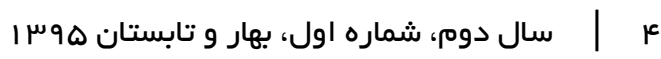




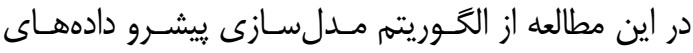

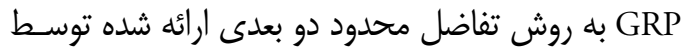

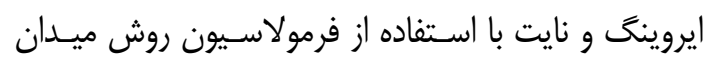
مغناطيسى عرضى يا مود TM، استفاده شده است. در اين

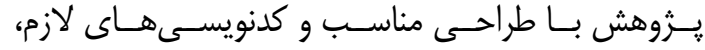

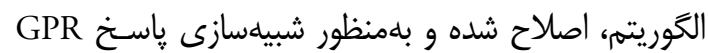

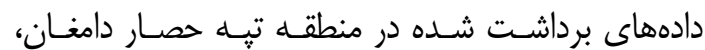
كدنويسى گرديده است. برداشـت دادهــاى صـحرايى بـر

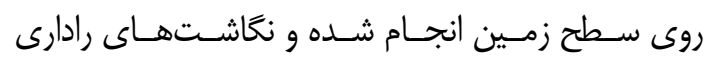
دادههاى GPR نيز بعد از يردازشهاى ضرورى و مناسـب توسط نرمافزار Reflexw، به نمايش درآمده است.

\section{f f - مبانى فيزيكى و نظرى روش GPR}

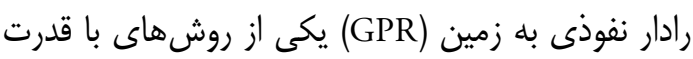

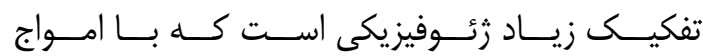

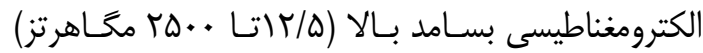

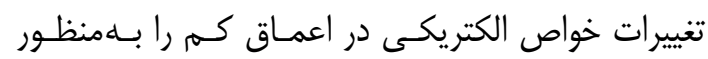

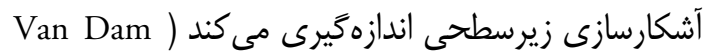

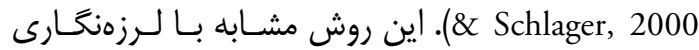

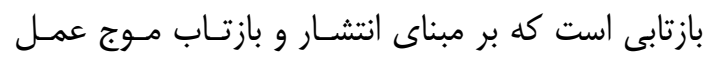
مى كند (Blindow et al., 2007). دستخاههاى اندازمخيرى

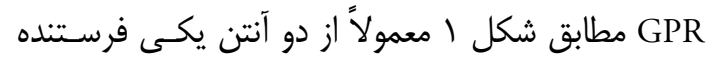

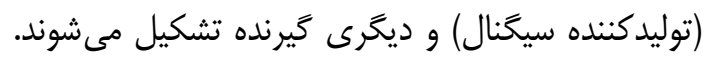
سيخنال ايجاد شده توسط آنتن فرستنده به درون زمسين

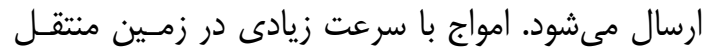

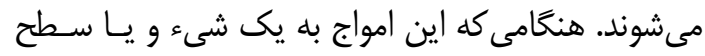

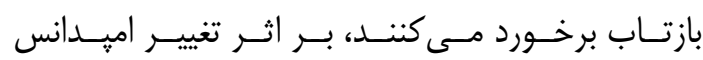

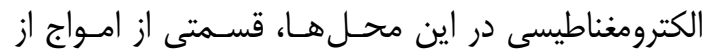

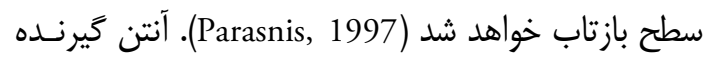

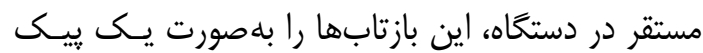
بالا نشان مى دهد و زمان سير حركت و دامنههاى بازتاب

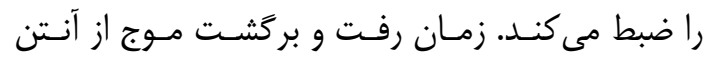

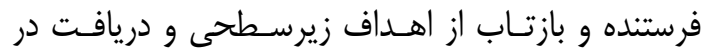

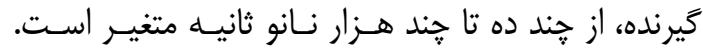
دسـتخاههــاى GPR در واقـع زمــان رسـيد امــواج را

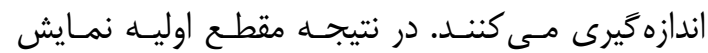

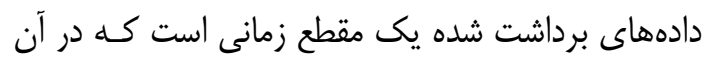

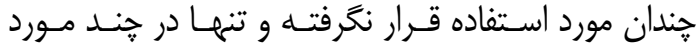

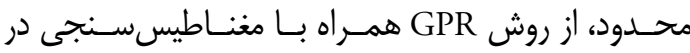
بررسى آثار باستانى مدفون در خاكهاى نزديك به به سـطح

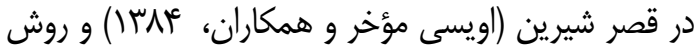
GPR به همراه توموكرافى مقاومت ويزه الكتريكى (ERT) در كاوشهاى باستانى منطقه تِّه حصار دامغـان (رشـمهـ-

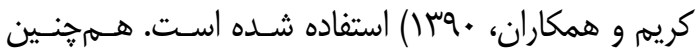
تعدادى از يزوهشكَران در اين زمينه نيز فعاليت داشتهانـــ

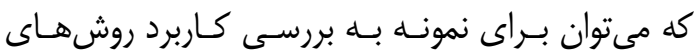

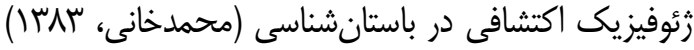

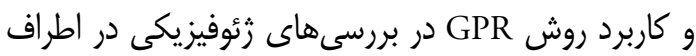

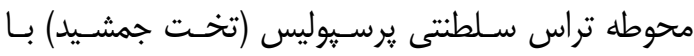

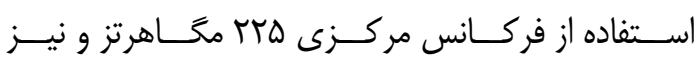
بهكـارَيرى روش الكتروستاتيك (Gondet et al., 2009)

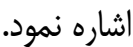

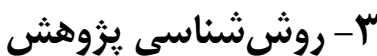

بلهور كلى مدل، بيان رياضى ايدهآلى از مقطع زمين است كه مدلسازى به دو روش ييشرو و وارون انجام مىشـود.

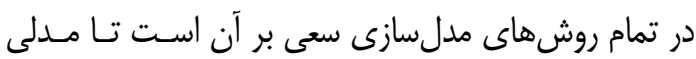
براى زير سطح تعيين شود كه نزديكترين و شـبيهترين ياسخ را به ياسخ دادههاى برداشت شـده داشـته باشـــ در

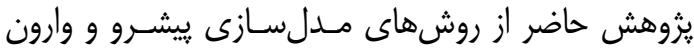

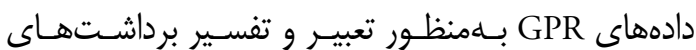
صحرايى با هدف آشكارسازى و شناسايى اهــاف مـدفون

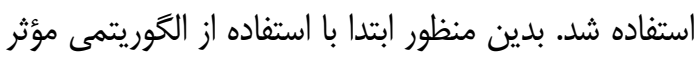
و با انجام كد نويسى در محيط GUI نرمافزار MATLAB، برنامه كامييوترى مناسبى براى انجـام مـدلسـازى وارون

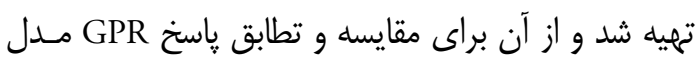

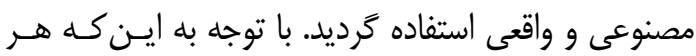

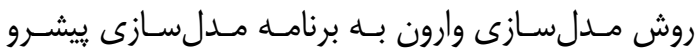
مناسب براى محاسبه ياسخ مدل در نقاط و فر كانسهـاى

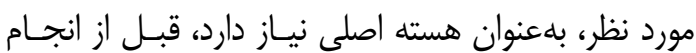

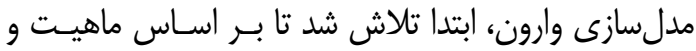
ويزگى هاى فيزيكى و هندسى هدف زيرزمينى مـورد نظـر در برداشت صحرايى، مدل مصنوعى آن تهيه شده و ياسخ دوبعدى آن به روش مدلسازى ييشرو، بهدست آيد.

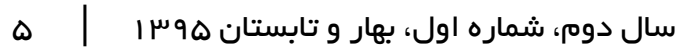


بسيارى از مواد زمـينشناسى، جريـانهـاى جابـهجـايى

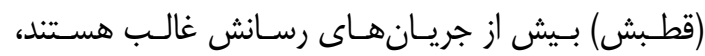

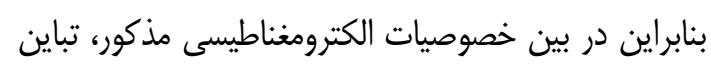

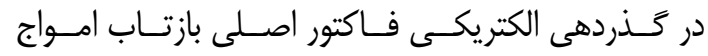

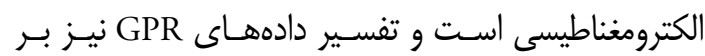

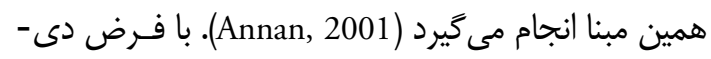
الكتريك بودن، رسانندگى پايين و در غياب مواد با تراوايى

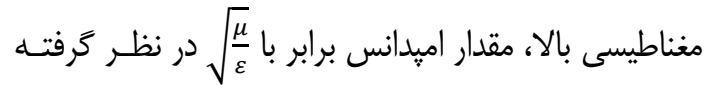

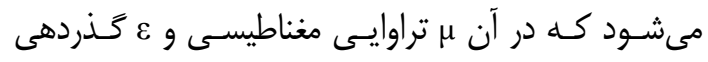

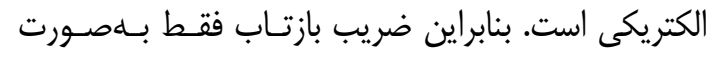

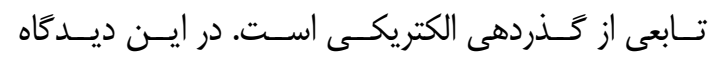

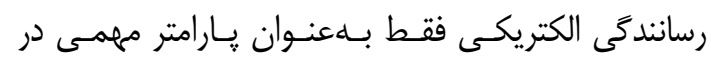

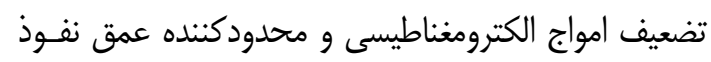
در نظـر ترفتـه مسى شـود (Jol, 2009). تغييـرات تراوايسى

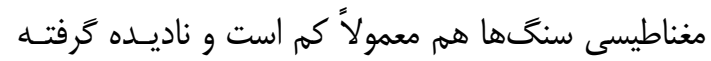

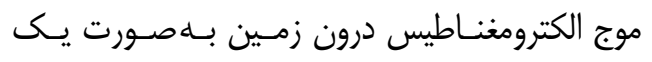

$$
\text { مى شود. }
$$

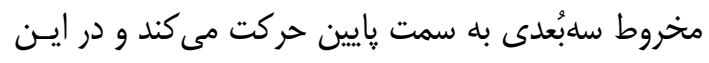
حين عواملى بر سرعت و اتلاف اين امواج تأثير مى كذارند.

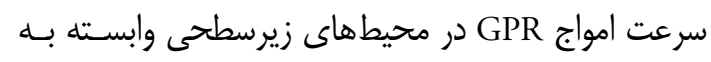

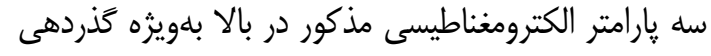

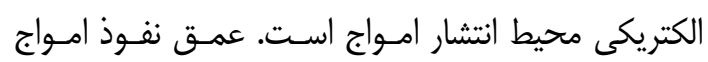

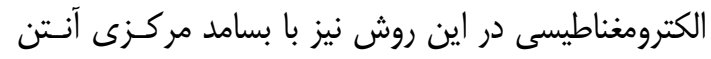

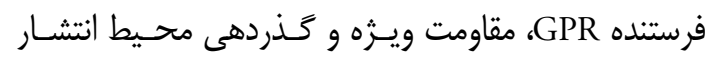

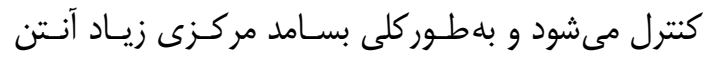

محور قائم، فاصله زمانى ارسال موج از فرستنده و دريافت با گيرنده را نشان مى دهد. براى تعيين موقعيـت مكـانى إنى

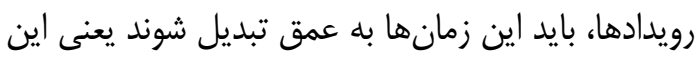

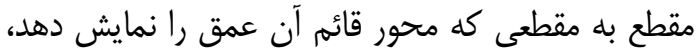

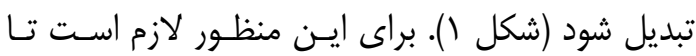
سرعت سير موج در ساختارهاى زيرسطحى منطقه مـورد بررسى، محاسبه شود. مههترين يارامترهـيـى كـهـ رفتـار

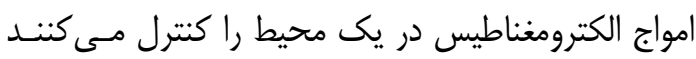

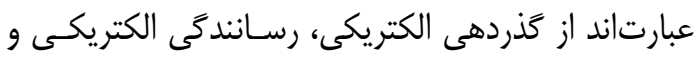
تراوايى مغناطيسى (Neal, 2004) كه در بين خصوصيات

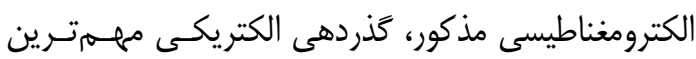

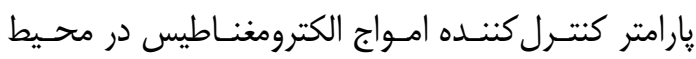

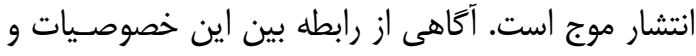

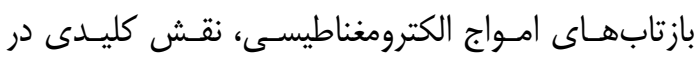
تفسير دادههاى GPR دارد. اكر برخورد و بازتـاب امـواج

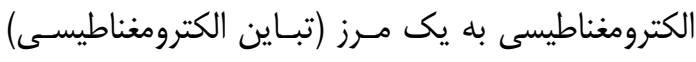

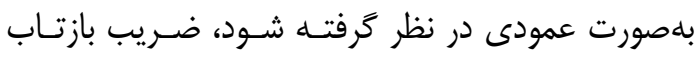

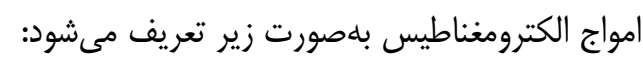
$R=\frac{Z_{2}-Z_{1}}{Z_{2}+Z_{1}}$ كه در رابطه بالا Z و $Z_{1}$ و اميدانس امواج الكترومغناطيسى در دو طرف مرز بوده و بلصورت زير تعريف مىشود: $\mathrm{Z}=\frac{\omega \mu}{\left(\omega^{2} \varepsilon \mu+i \omega \mu \sigma\right)^{1 / 2}}$ كــه در ايــن رابطــهـ

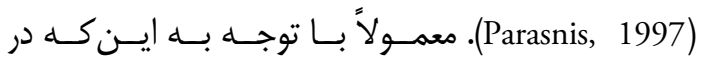

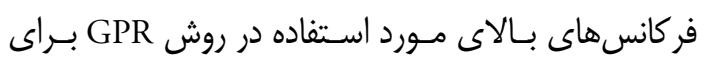

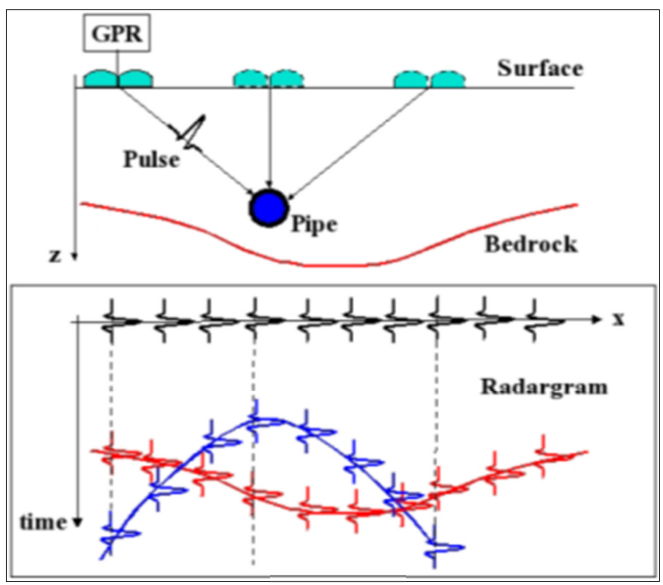

(ب)

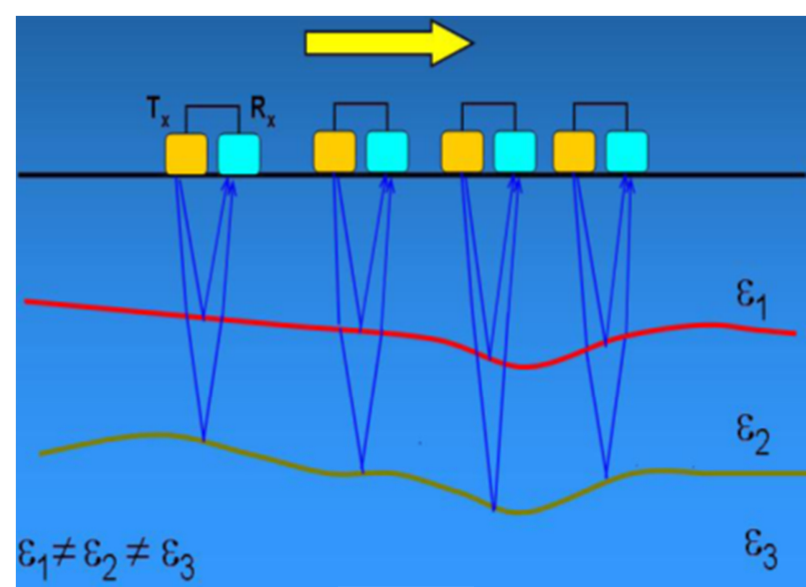

(الف)

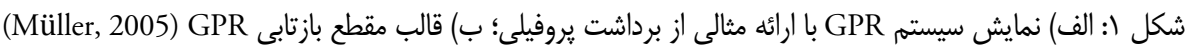


استفادههاى مختلف ساخته شدهاند. طبقه دوم حصـار (II)

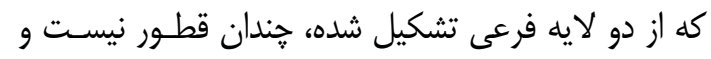

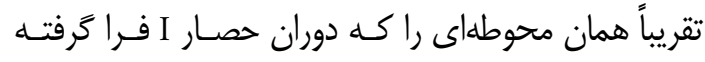

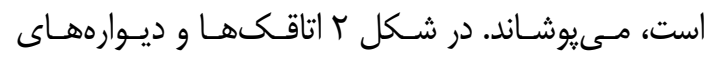

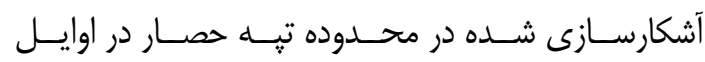
دهه •rا9 ميلادى نشان داده شده است. قطر آثار باستانى حصار III با جديدترين طبقه حدود fأ متر اسـت (اشـميت،

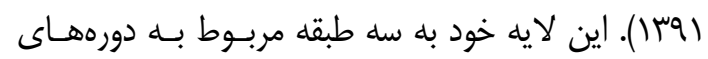

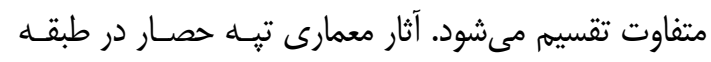

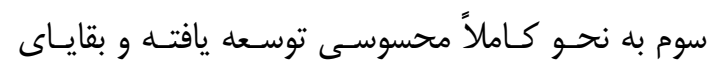
ساختمان بزركى در اين طبقه مشاهده مى كَردا (افشـارفر،

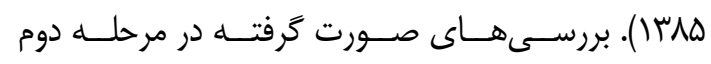

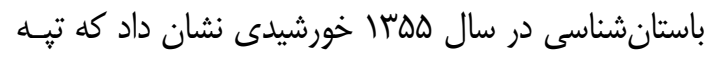

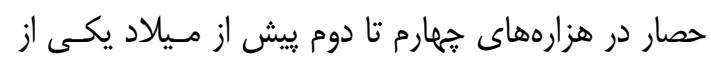

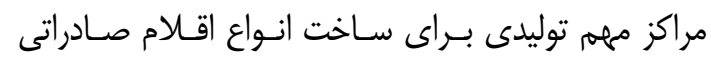

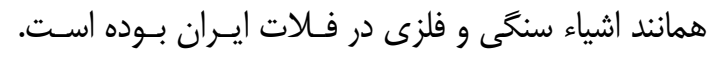

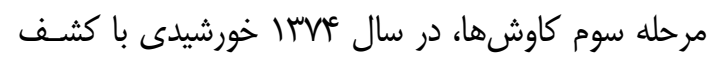

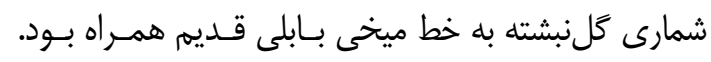

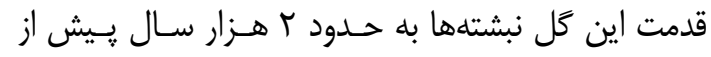

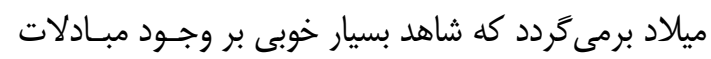

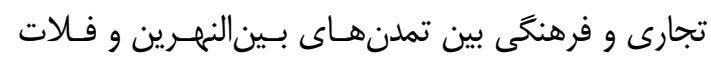

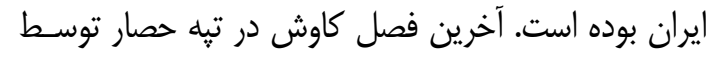
هيئتى از يزوهشكده باستانشناسى، در سال هربّا انجـام

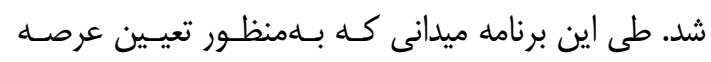
واقعى محوطه انجام شد، شواهد روشنى مبنى بـــر استقرار

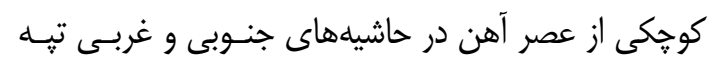

فرستنده و رسانندگى بالاى مواد زير سطح زمـين موجـب

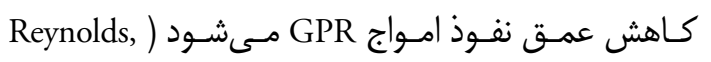

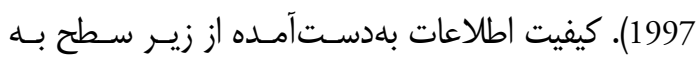

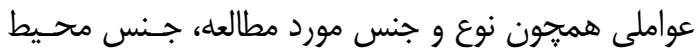
به لحاظ زمينشناسى و عمق مورد مطالعه بستخى دارد.

\section{ه- ي يشينه تاريخى منطقه برداشت دادهها}

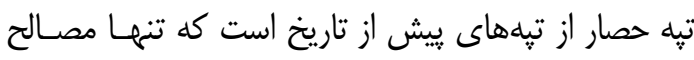
موجود در محيط براى ساختن بناهاى آن خاك رس بـ بـ بـوده

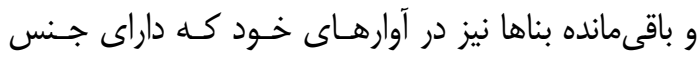

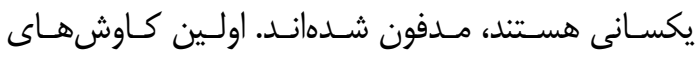

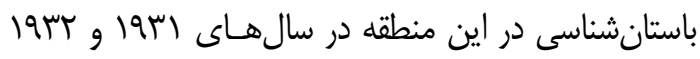

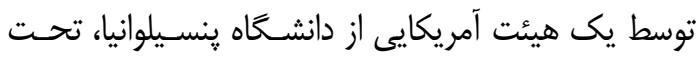

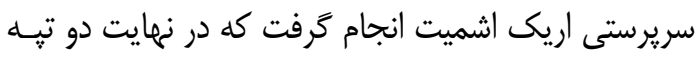

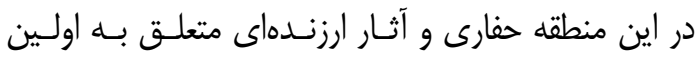

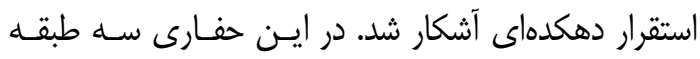
اصلى مشخص شد، كه هر طبقه شامل خند لايه باستانى

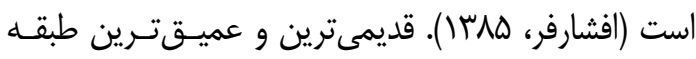

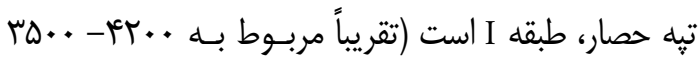

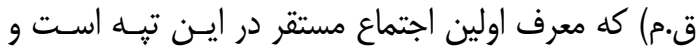

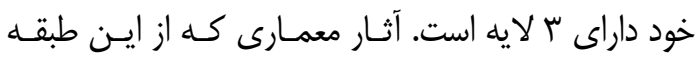

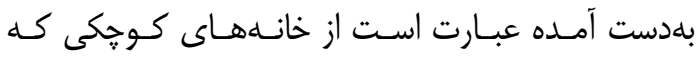

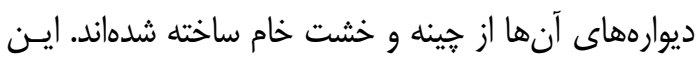

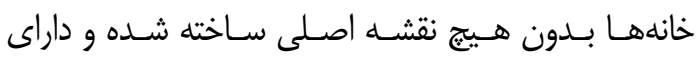

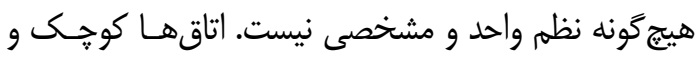

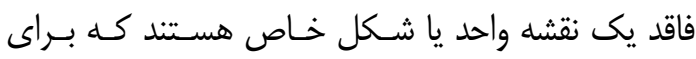

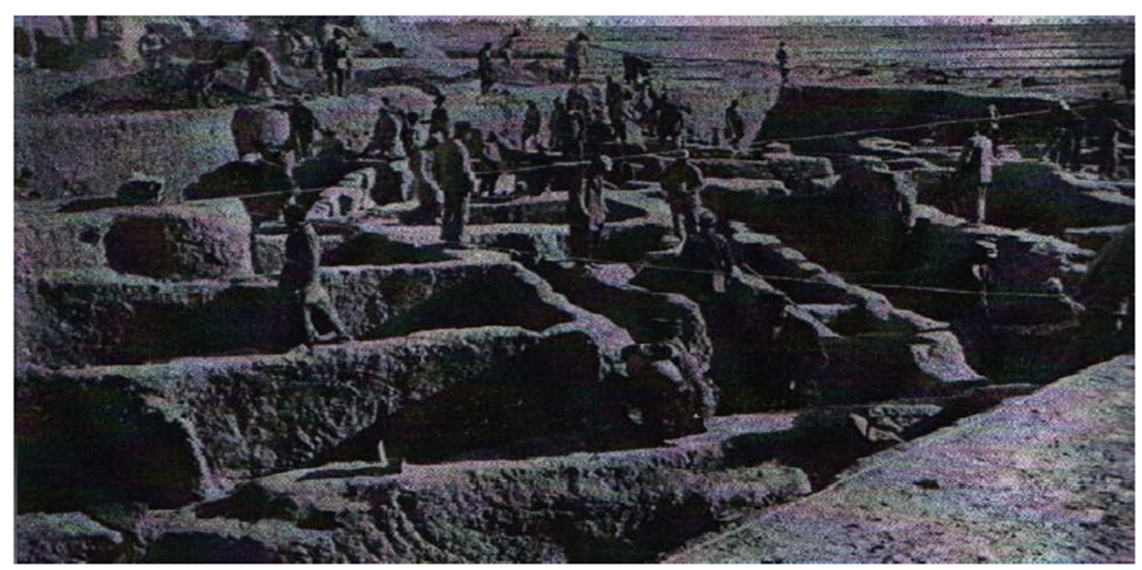

شكل r: كاوشهاى انجام شده در محدوده تֶه حصار در اوايل دهه •.بحا ميلادى و نمايش اتاقكها و ديوارهها

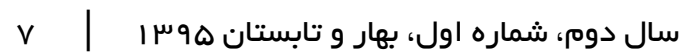




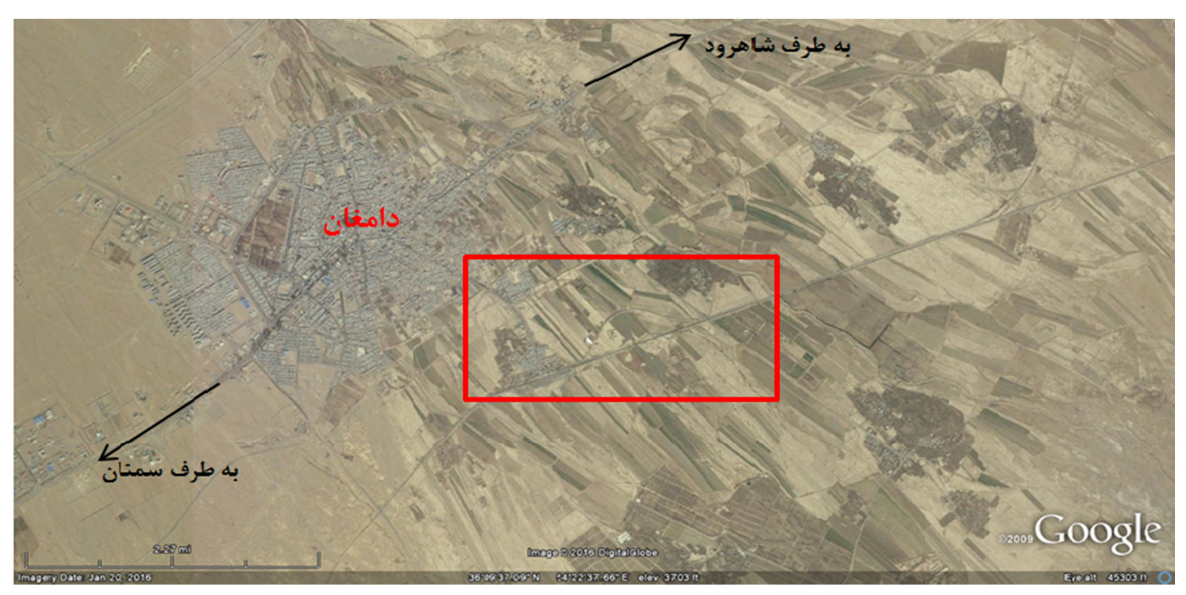

شكل "ا: موقعيت مكانى تيهحصار دامغان (Google Earth, 2015)

بامنظور انجام مطالعـات باسـتانشناسـى محــدوده و

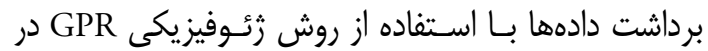

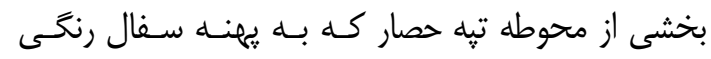

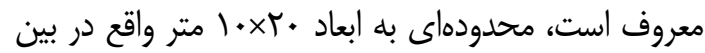

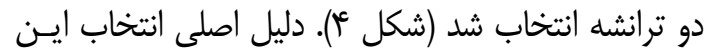
محدوده، هموار بودن آن است كه عمليات برداشت دادهها

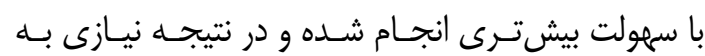

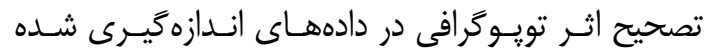
نيست. عمليات برداشت دادهها بر اساس ترانشههاى حفـر شده قديمى، طراحى شده و دادهها با يـك شـبكه مـنظهم

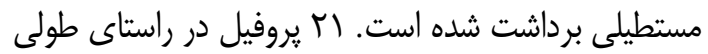

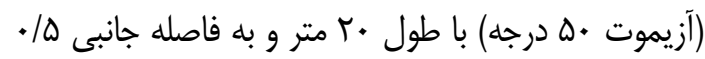

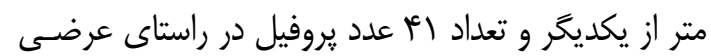
(عمود بر راستاى يروفيل هاى طولى) به طول • م متر و
حصار، كار گاه ذوب كانسنَ مسس و گورسـتانى از همـين

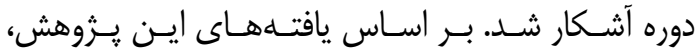

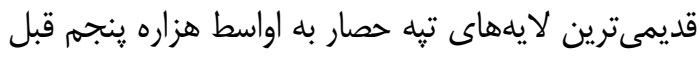

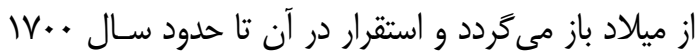

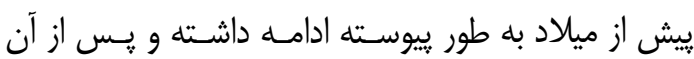
هيج گاه مورد سكونت قرار نخرفته است (اشميت، (وسا).

\section{צ- برداشت دادههاى GPR در منطقه تيه حصار دامغان}

محوطه باستانى تيهحصار دامغـان بـا وسـعت بـيش از

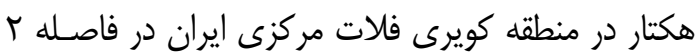

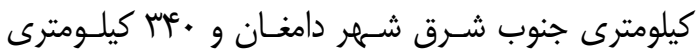

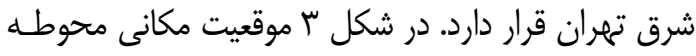
باستانى تيه حصار دامغان نشان داده است.

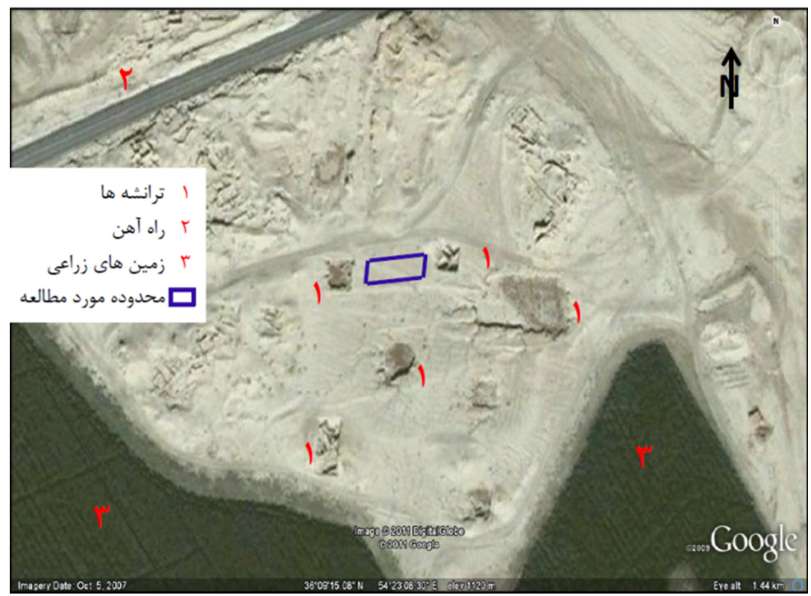

شكل זٔ: عكس هوايى از محدوده مورد مطالعه و ترانشههاى حفر شده (Google Earth, 2015) 


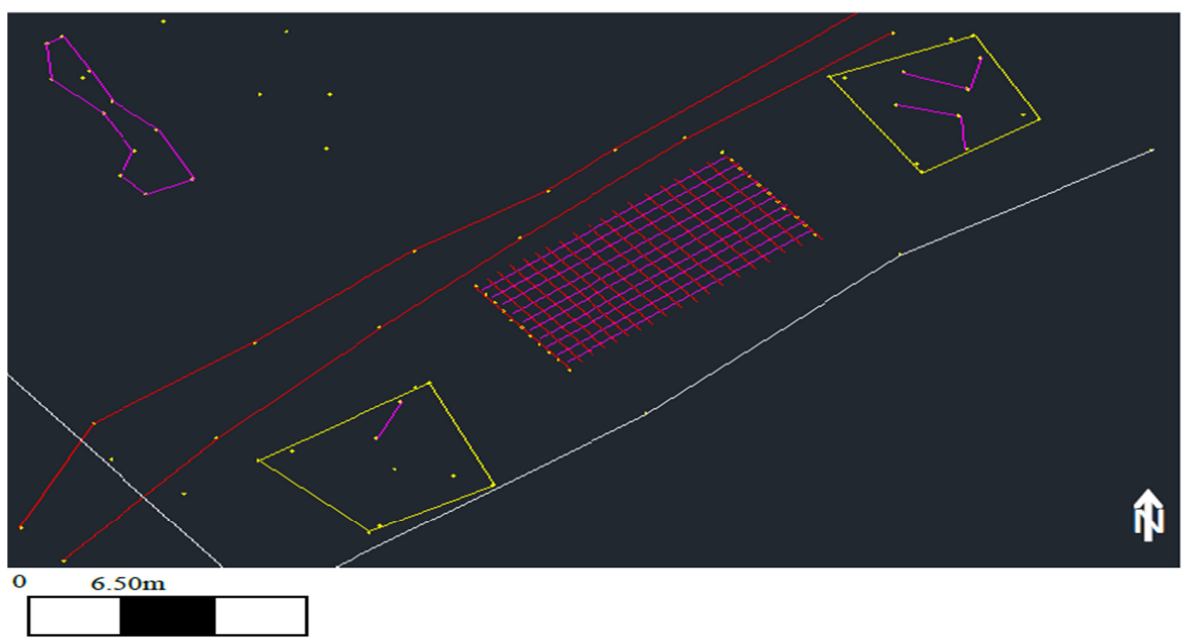

شكل ه: شبكه برداشت دادههاى GPR

فيلترهاى مختلف و بررسى اثر آنهـا بــر روى مقـاطع در

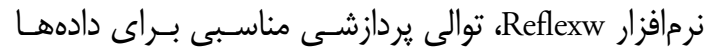

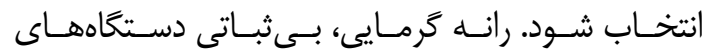

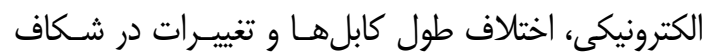

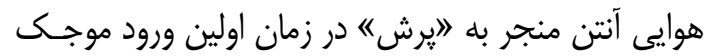

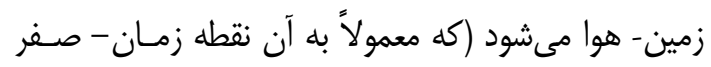

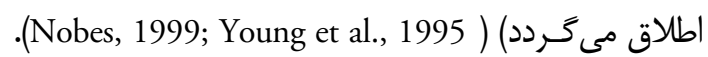
اين زيديده روى موقعيت مرز زمين و هوا در مقطع، زمـان

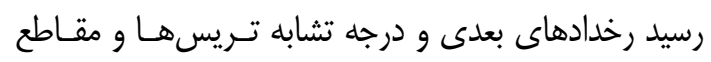

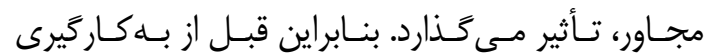

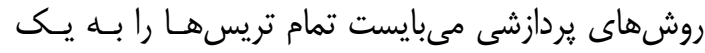

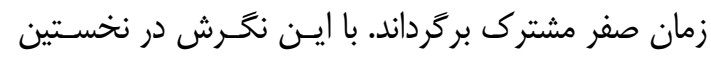

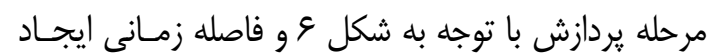

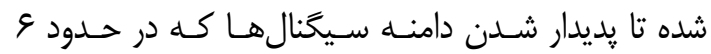

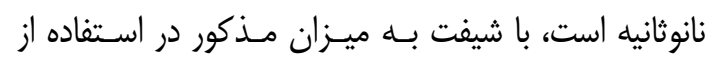

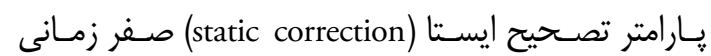
نحخاشت رادارى تصحيح مىشود.

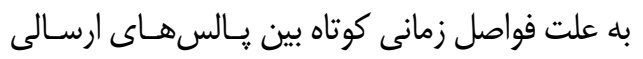

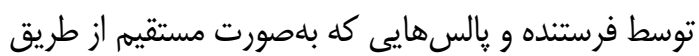

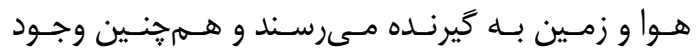

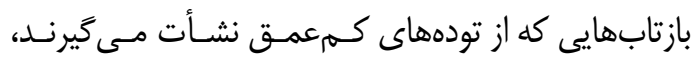
كيرنده از سيكنال اشباع مىشود (Neal, 2004). اين مسأله

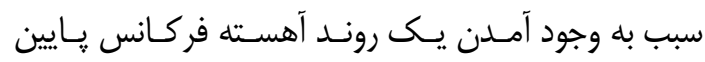

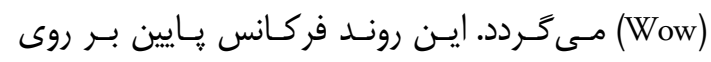

فاصله جانبى ه/• متر طراحى شد (شكل ه).

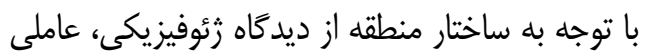
كه به نظر مىرسد مىتواند باعث به وجـود آمـدن تبـاين فيزيكى مطلوب بين اهداف زيرسطحى مورد نظر و محيط دربر گيرنده شود، متراكمتر بودن ساختهاى مدفون نسبت

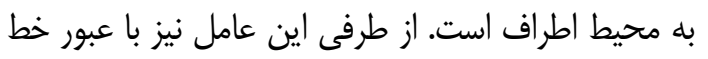

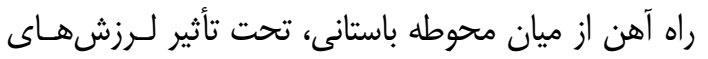

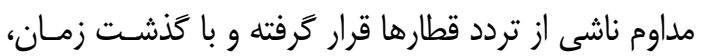

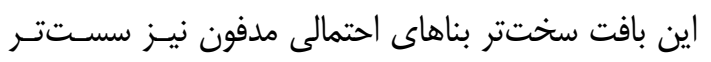

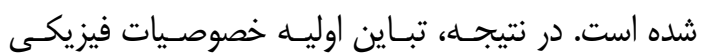

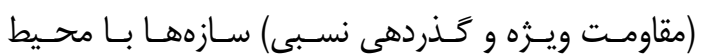

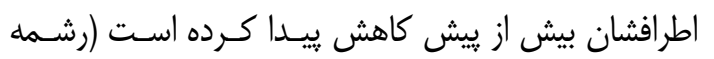
كريم و همكاران، •وسان).

\section{GPR يردازش دادههاى واقعى - V}

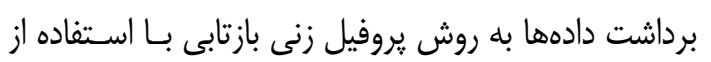
دستخاه رادار Noggin Plus مجزز به آنتنهاى يوشـشدار

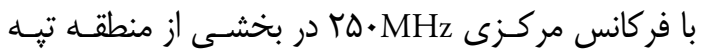

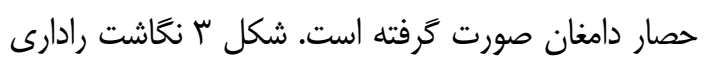
دادههاى خام برداشت شده منطبق بر يكى از يروفيلهـاى

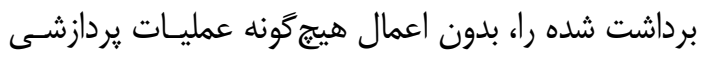

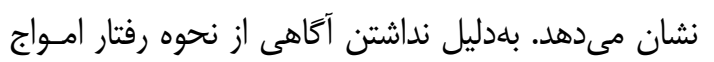

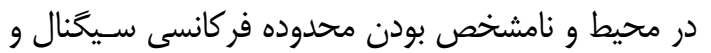
نوفه، با استفاده از روش آزمونوخطا سعى شد تا با اعمـال 


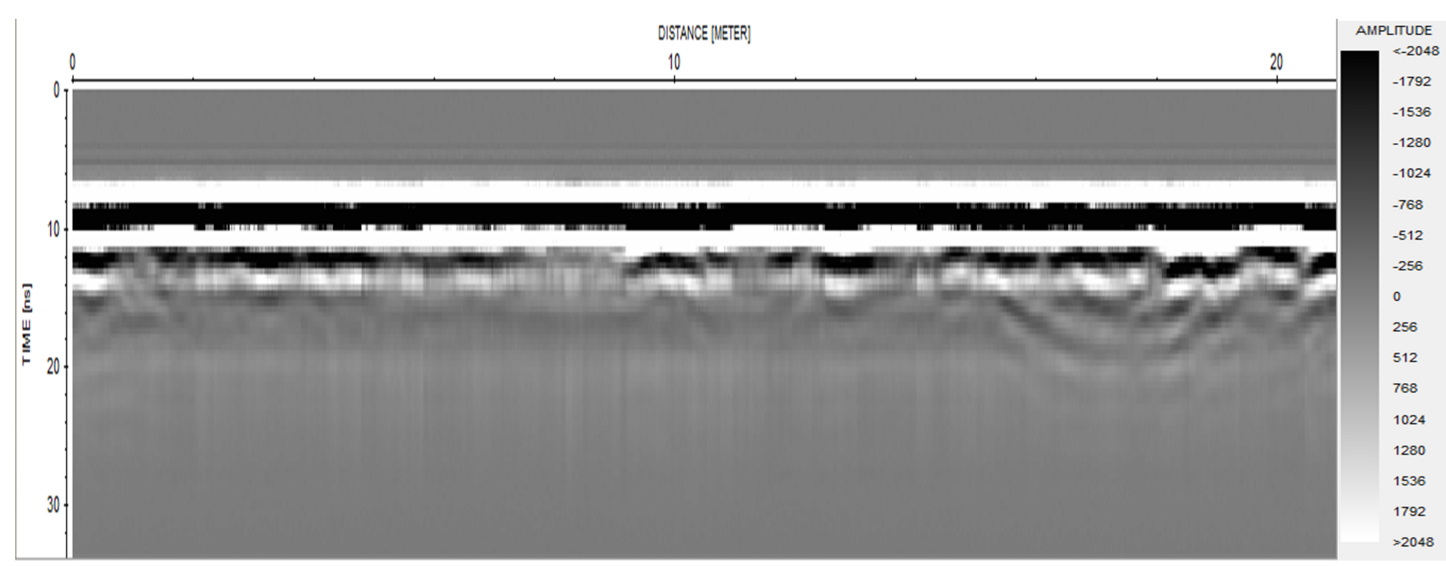

شكل و· نمايش مقطع نغاشت رادارى دادهاى خام برداشت شده

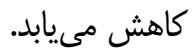

از جمله مهمترين عوامل تضـعيف انـرزى سـيخنال،

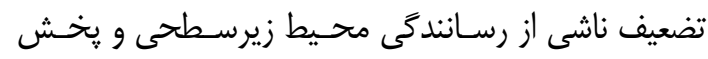

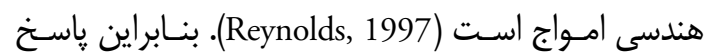
دريافتى از تودههاى زرف، ضعيفتر است. براى حـل ايـن

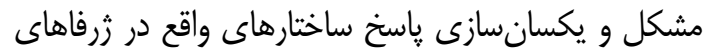
مختلف با استفاده از بهـرههـا (Gain)، تـوان سـيخَنال در زرفاهاى بيشتر افزايش مىيابــــ در ادامـهـ بــراى تبــديل

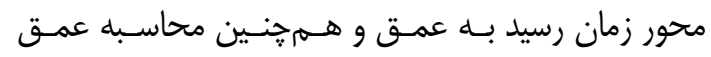

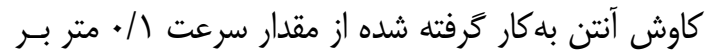

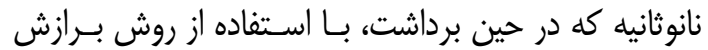
هذلولى، سرعت سـير مـوج در محيط معـادل m/ns / / /.

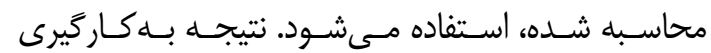
يارامترهاى يردازشى مورد اشاره، در نخاشت رادارى شـكل

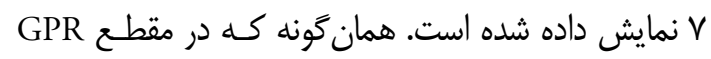

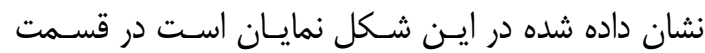

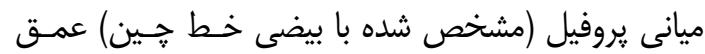

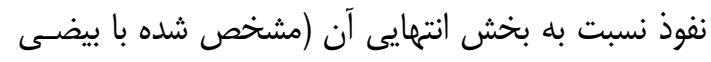

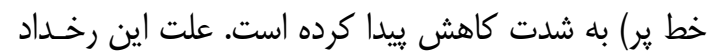

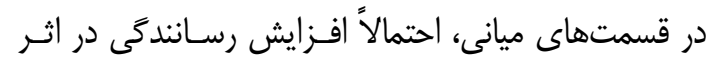
وجود بافت سستتر و رسوبات دانهريزى است كـه در اثر تخريب سازهها و يا روى هم انباشته شدن رسوبات ناشسى

از جريانات حاصل از ريزشهاى جوى است.

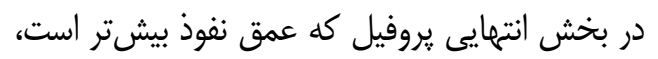

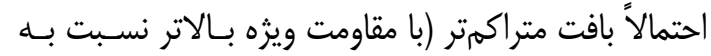
بخش ميانى) وجود دارد كـهـ در ايـن صـورت ايـن بافـت فئس
فر كانسهاى بالاتر قرار كرفته و آنها را مغشوش مسى كنـــ.

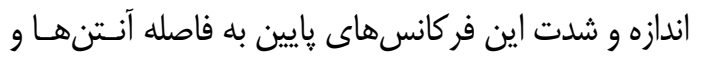

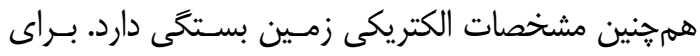

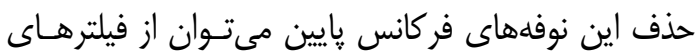

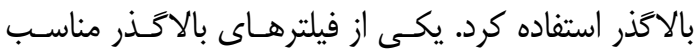

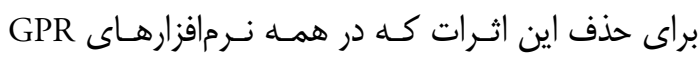
موجود است، فيلتـر دىواو (Dewow) اسـت. خوشـبختانه تمام سيستمهاى ييشرفته GPR بلهورت خودكـار فيلتـر

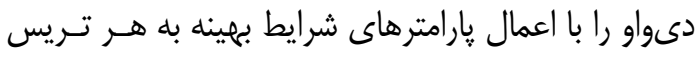

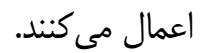

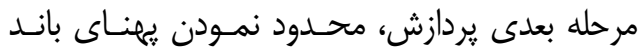

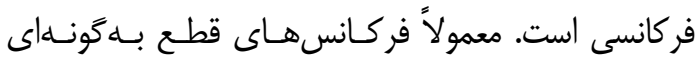

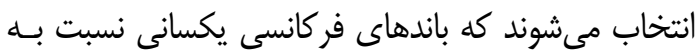
فركانس مركزى ايجاد نماينــ (Davis \& Annan, 1989).

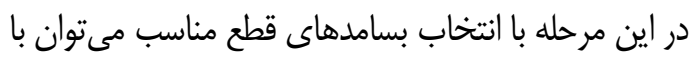

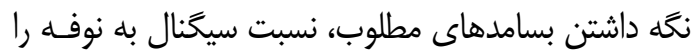

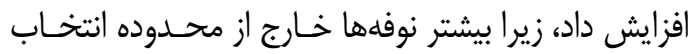

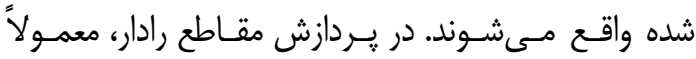

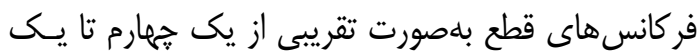
دوم و دو برابر تا جِهار برابر فر كانس مركزى آنتن، اعمـال

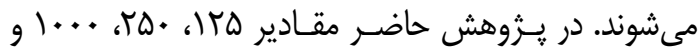

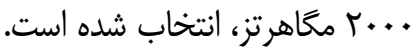

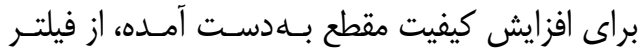
دوبعدى بردارنده زمينه (Background Removal) استفاده مى شود. از سوى ديخر توان سيخنال انتشارى در تودههاى

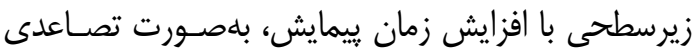




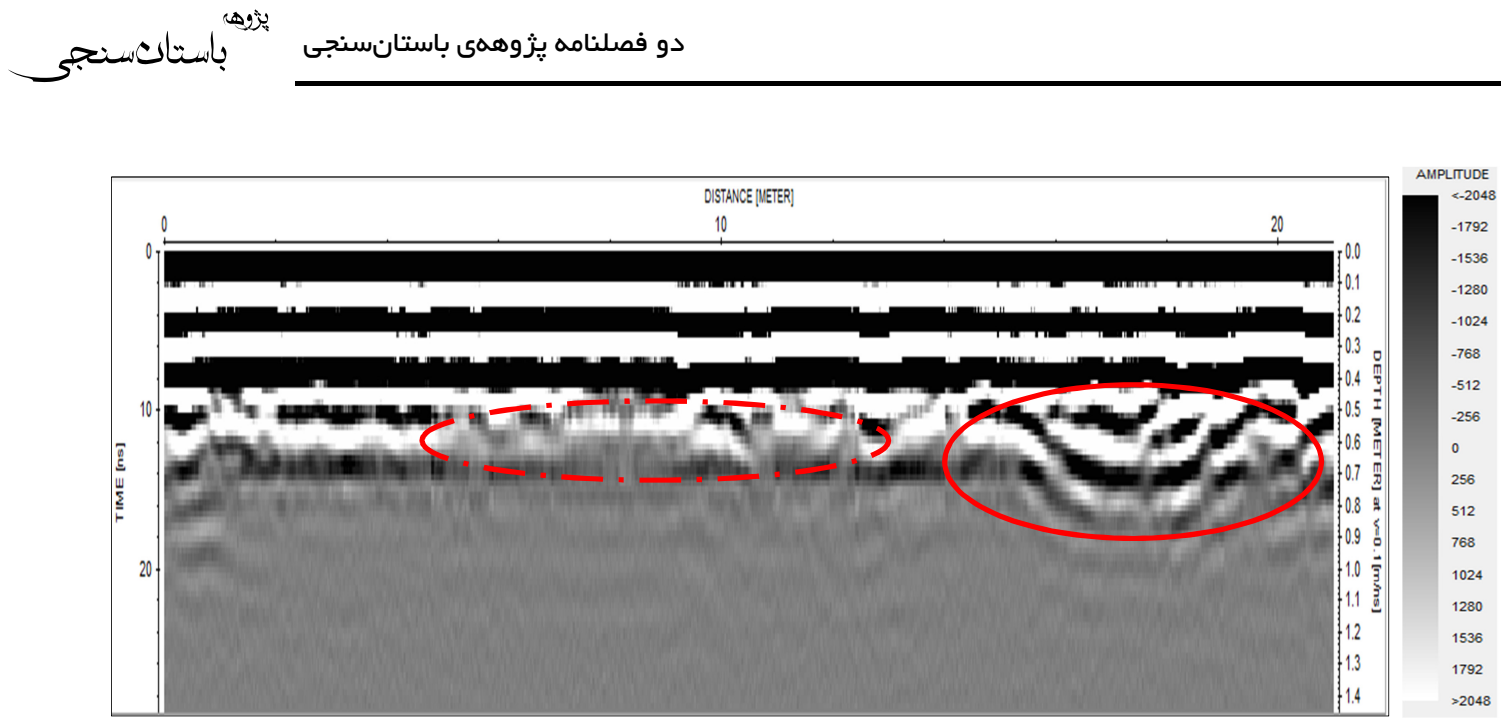

شكل V: نمايش مقطع زمانى و عمقى بروفيل برداشت شده با اعمال مراحل يردازشى مناسب

كَرديده است. براى مدلسازى ياستخ GPR هـدف مـورد

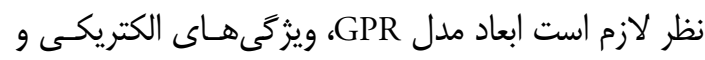

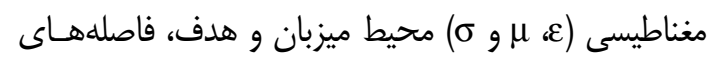

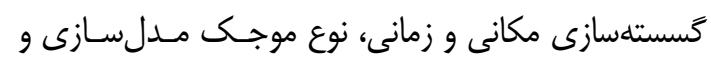

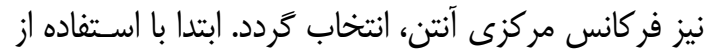
مدلسازى ييشرو و طراحى مدل بر اساس شرايط محيط الميط

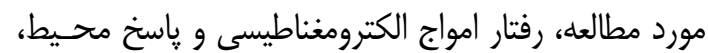

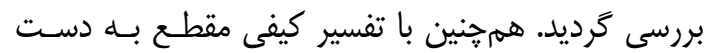

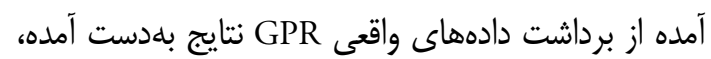
با شرايط واقعى زمين، مقايسه خواهد شد. بلهمنظور شبيهسازى دادههاى GPR برداشت شـــ در مر

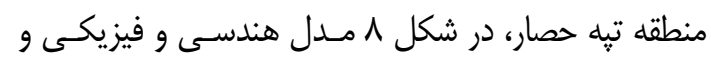
ياسخ GPR متناظر با يكى از يروفيلهاى برداشت شده در

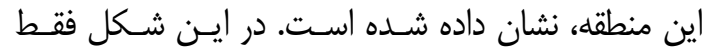

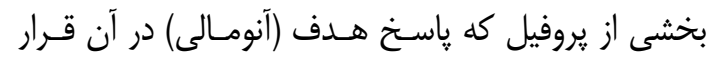

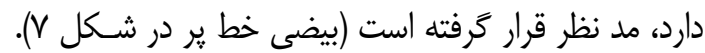

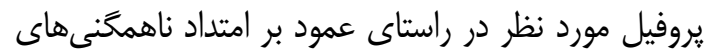

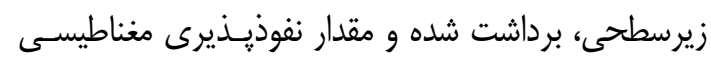

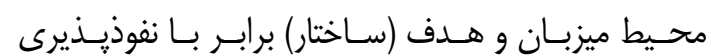
مغناطيسى فضاى آزاد، منظور شده است.

\section{9- مدلسازى وارون دادههاى GPR}

در مدلسازى وارون سعى مىشود تا بر اسـاس دادههـاى

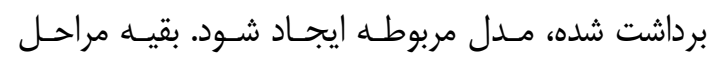

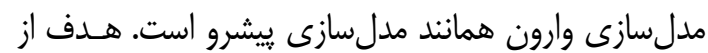

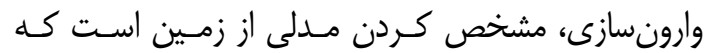

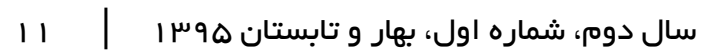

متراكم مىتواند مربوط به سازمهاى مدفون زير سطح باشد. بيضى خط ير مشخص كننده نواحى با مقاومت ويزه مرئ

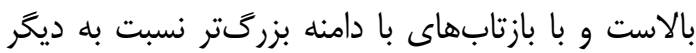
بخشها قابل تشخيص است. ناهمكَىهاى اين قسمت بإن ناشى از ديوارههاى مدفون احتمالى هستند كه عمق إنق إنق قرارگيرى اين آنومالى كمتر از • ا سانتىمتر است.

\section{APR مدلسازى ييشرو دادههاى} روش GPR بر اساس تئورى الكترومغناطيس استوار است.

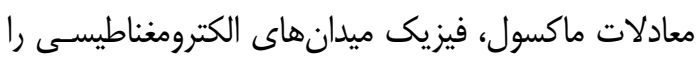

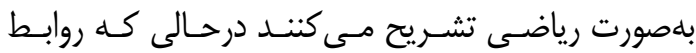

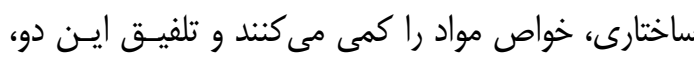

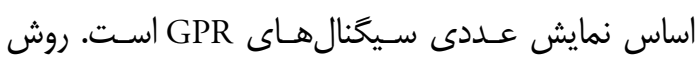
اختلاف محدود مبتنى بـر تخمـين معـادلات ديفرانسـيلى حاكم بر شرايط مسئله GPR از بسط سرى تيلور است. در

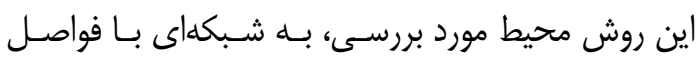

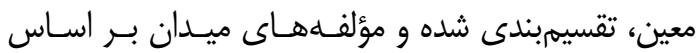
سلول يیى (Yee, 1966) و روابط ماكسول، براى يك زمـان

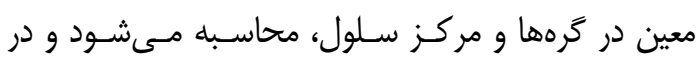

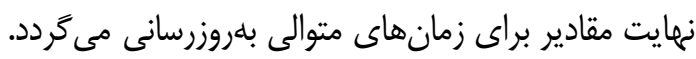

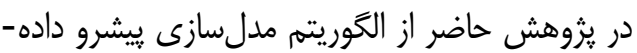

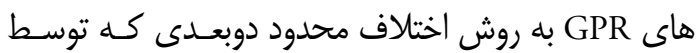

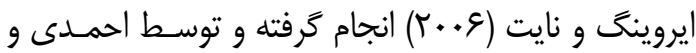

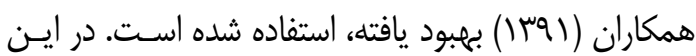
تحقيق الكوريتم اصلاح شده براى شبيهسازى ياسخ (باسخ دادههاى برداشتى در منطقه تيـه حصـار دامغـان اسـتفاده 


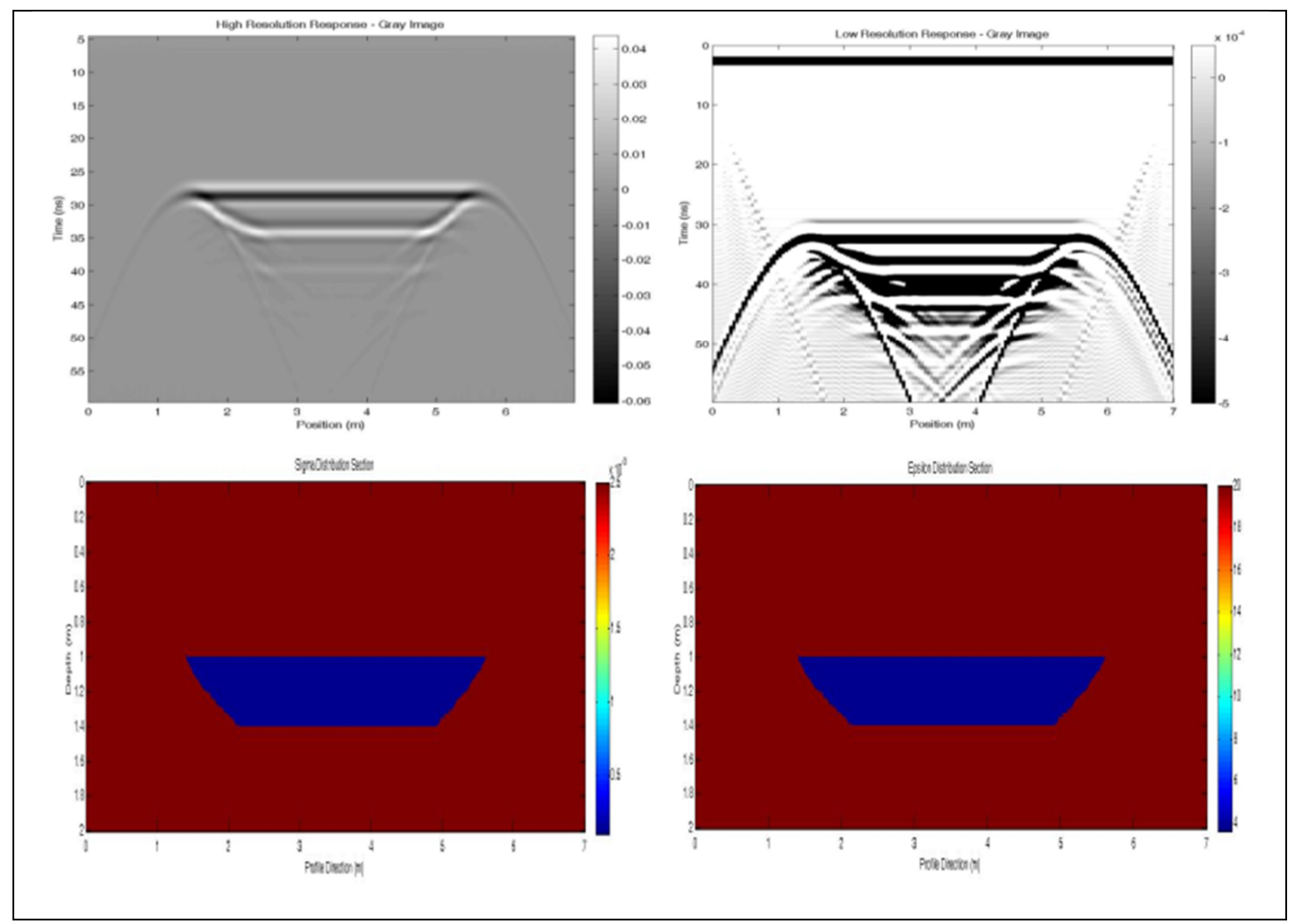

شكل م: مدل هندسى و فيزيكى شامل هند ضلعى دوبعدى در قسمت پايين شكل و پاسخ سامانه GPR در قسمت بالاى شكل (تفكيكيذيرى بالا

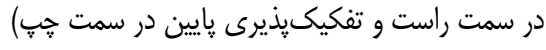

مربعات خطا -اخـتلاف بـين مقـادير ياسـخهـاى مــل و

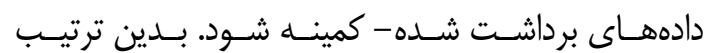
يارامترهايى از مدل بايد تغيير كنند تا مجموع مربعات خطا بردا كاهش يابد. در اين يزوهش از رابطه به هنجـار (نرمـاليزه)

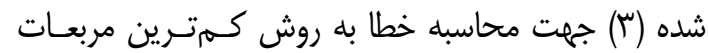
خطا، استفاده شده است:

RMS error $=\sqrt{\frac{\sum\left(\frac{\mathrm{Ez}_{\text {real }}-\mathrm{Ez}_{\text {model }}}{\mathrm{Ez}}\right)_{\text {real }}}{\mathrm{n}}} \times 1$.

نتيجه حاصل از مــدلسـازى وارون بــراى دادههـاى

صحرايى برداشت شده در منطقه مورد نظر همراه با ميزان

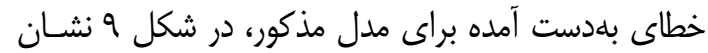

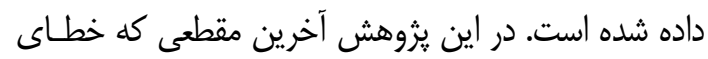
كمترى داشته است، بلعنوان نتيجه آورده شده است.

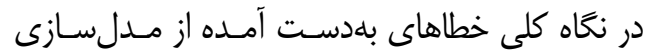

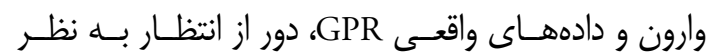
مىرسد كه البته عوامل مختلفى در بالا بودن ميـزان ايسن وهان

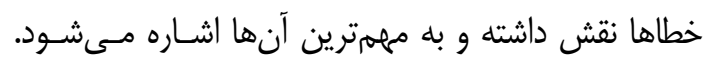

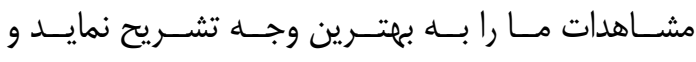

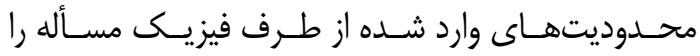
ياسخ گو باشد. در اين يزوهش سعى بر آن است تا از روش

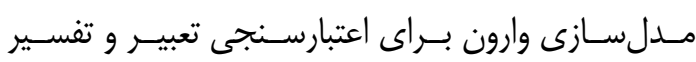

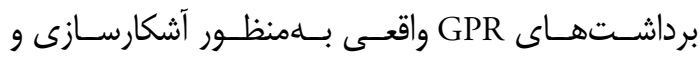
شناسايى اهداف مدفون استفاده شود. براى اين منظور بايد نتايج مدلسازى وارون با نتايج مدلسازىهاى انجامدام شده

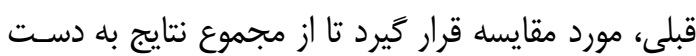

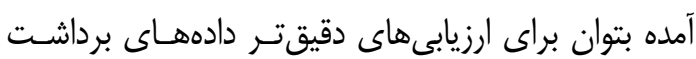

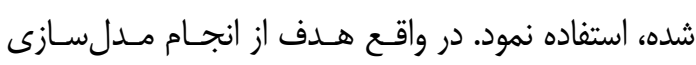

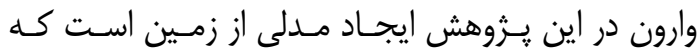
ياسخى مشابه دادههاى اندازهگيرى شده داشته باشد. ايسن إنـ

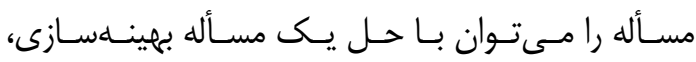

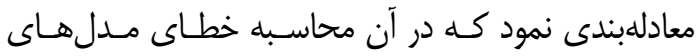

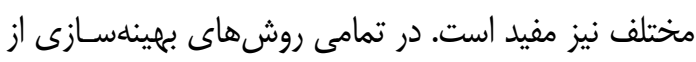
جمله روش بهينهسازى كمترين مربعات خطا، مــل اوليـه

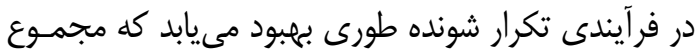

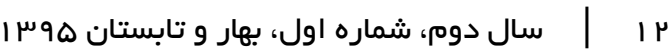




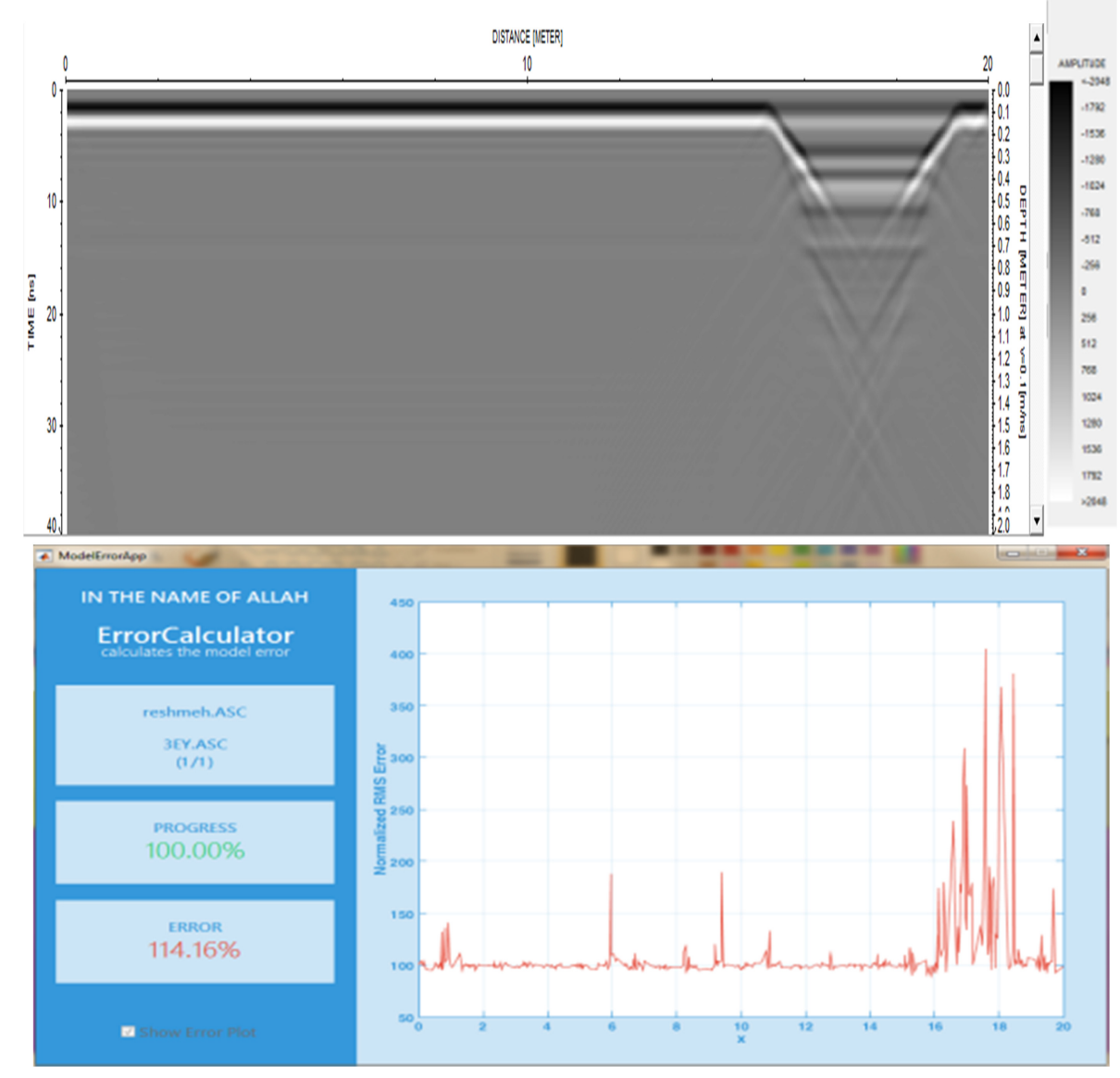

شكل ج: مدل زمين با بيشترين شباهت به مقطع حاصل از برداشت دادهاى صحر ايى در منطقه تبه حصار دامغان همراه با ميزان خطاى بلهدست آمده

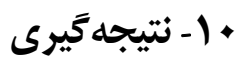

در يزوهش حاضر از روش GPR با هدف كاربرد در زمينـه

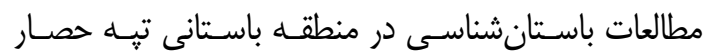

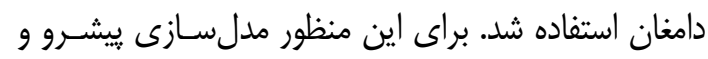
وارون دادههاى GPR بـراى نخاشـت رادارى منطبـق بــر يكى از يروفيلهاى شاخص برداشت شده در اين منطقـه،

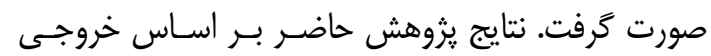

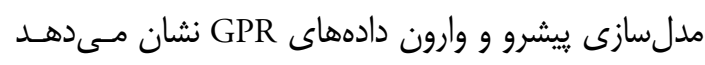
كه ميزان تطابق ياسخ مدلسازى ييشرو با نگَاشت رادارى

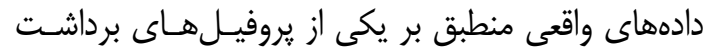

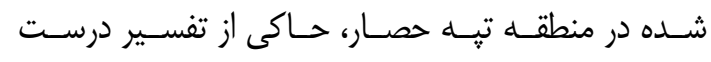

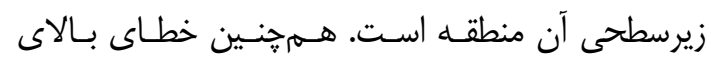

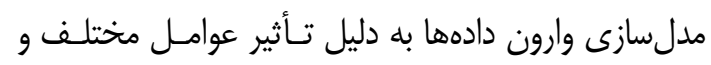

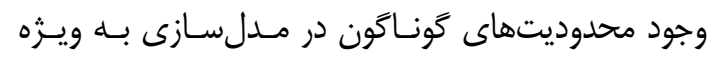

معمولاً زمينهاى واقعى بسيار يِيجيده بوده و مقادير

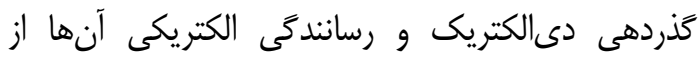
سطح زمين تا يك عمق مشخص، متفاوت است، بنابراين زمانى مىتوان بهطور دقيق اين مقادير را تعريف نمود كه

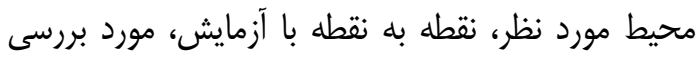

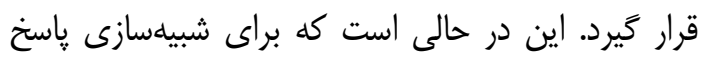

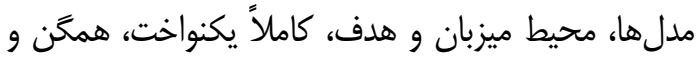

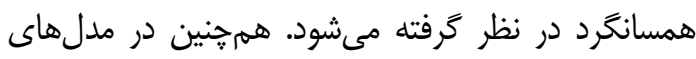
واقعى زمين، انواع نوفهها وجود دارد كه اعمال آنها در مدلسازى مصنوعى، امكانيذير نيست. علاوه بر اين به دليل وجود محدوديتهاى گوناگون در تمامى الخوريتهها و نرمافزارهاى مدلسازى ييشرو، امكان انجام مدلسازى

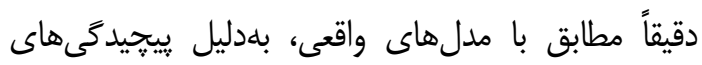

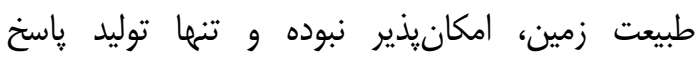
مدلهاى ساده امكانيذير است. 


$$
\begin{aligned}
& \text { موردى سايت تبه حصار دامغان، بإنزدهمين همايش }
\end{aligned}
$$

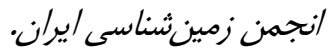

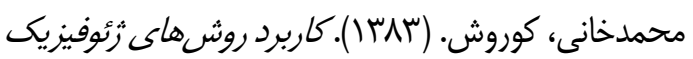

$$
\begin{aligned}
& \text { اكتشافى در باستانشناسى (آركئو ثئوفيزيك)، مطالعه رئه }
\end{aligned}
$$

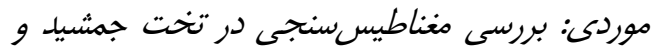

$$
\begin{aligned}
& \text { يإساركاد، קِيانانامه كارشناسى ارشد، باستانشناسى، } \\
& \text { دانشگاه تربيت مدرس. }
\end{aligned}
$$

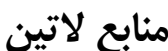

Alaamer, H.A. (2015). Modeling of GPR Profile: An Example from Archaeological Site in Basrah, Iraq. Basic Sciences and Applied Research, 1(3): 1-10.

Al-Nuaimy, W., Huang, Y., Nakhkash, M., Fang, M. T. C., Nguyen, V. T., \& Eriksen, A. (2000). Automatic detection of buried utilities and solid objects with GPR using neural networks and pattern recognition. Journal of applied Geophysics, 43(2), 157-165.

Annan, A. P. (2001). Ground Penetrating Radar Workshop Notes: Sensors and Software.

Arciniega-Ceballos, A., Hernandez-Quintero, E., Cabral-Cano, E., Morett-Alatorre, L., DiazMolina, O., Soler-Arechalde, A., \& ChavezSegura, R. (2009). Shallow geophysical survey at the archaeological site of San Miguel Tocuila, Basin of Mexico. Journal of Archaeological Science, 36(6), 1199-1205.

Arısoy, M. Ö., Koçak, Ö., Büyüksaraç, A., \& Bilim, F. (2007). Images of buried graves in Bayat, Afyon (Turkey) from high-resolution magnetic data and their comparison with preliminary excavations. Journal of archaeological science, 34(9), 1473-1484.

Aydin, A., Baykan, O., and Akyol, E. (2014). Detecting ancient water distribution system using GPR in Patara, Antalya, Turkey. Multidisciplinary Engineering Science and Technology (JMEST), 1(5): 32-38.

Bergmann, T., Robertsson, J. O., \& Holliger, K. (1998). Finite-difference modeling of electromagnetic wave propagation in dispersive and attenuating media. Geophysics, 63(3), 856-867.

Bourgeois, J. M., \& Smith, G. S. (1996). A fully three-dimensional simulation of a groundpenetrating radar: FDTD theory compared with experiment. IEEE Transactions on Geoscience and Remote Sensing, 34(1), 36-44.

Brandt, O., Langley, K., Kohler, J., \& Hamran, S. E. (2007). Detection of buried ice and sediment layers in permafrost using multi-frequency Ground Penetrating Radar: A case examination on Svalbard. Remote Sensing of Environment, 111(2), 212-227.

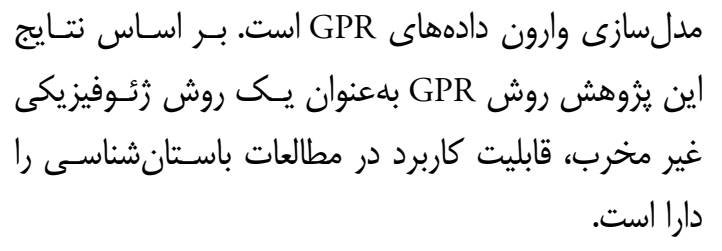

\section{سباسگز ارى}

اين مقاله مستخرج از پاياننامه كارشناسى ارشد نويســنده

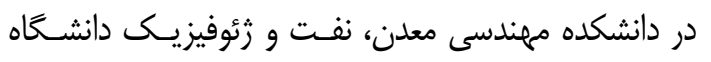

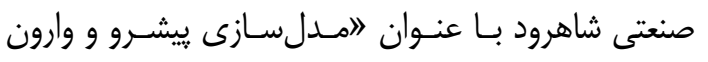

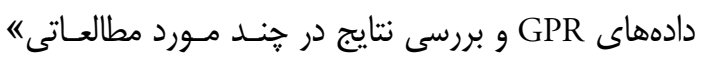

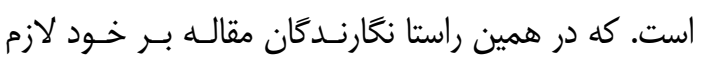

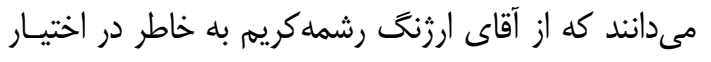
قرار دادن دادههاى برداشـت شـــه در منطقـهـ تبـهـ حصـار

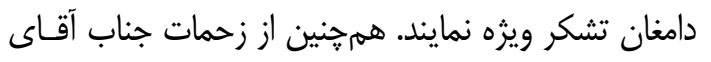

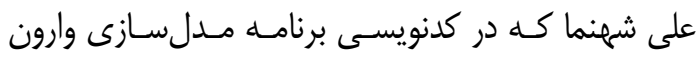

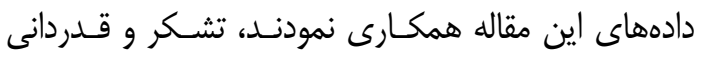
مى تردد.

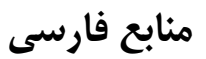

احمدى، رضا، فتحيانيور، نادر، و نوروزى، غلامحسين.

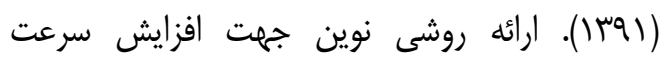

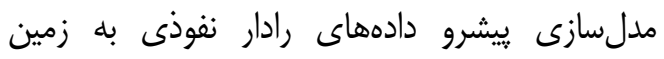
(GPR)

$$
\text { مهندسى معلن /يران، دانشخاه تهران. }
$$

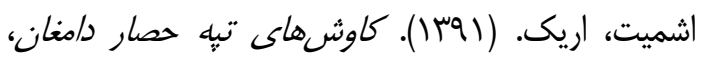

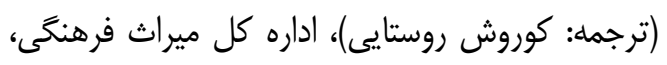

$$
\text { صنايعدستى و كَردشكرى استان سمنان. }
$$

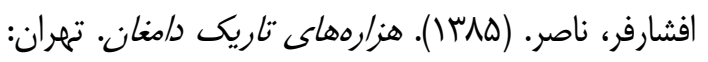

$$
\text { انتشارات يازينه. }
$$

اويسى موخر، محسن، قاسمى، وحيد، و شاه نظرى،

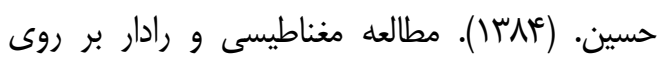

طاقهاى عمارت تاريخى خسرو در شهر قصر شيرين،

$$
\text { دوازدهمين كنفرانس ثرئوفيزيك /يران. }
$$

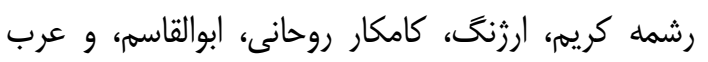

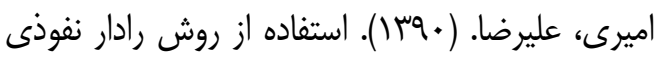

به زمين (GPR) در كاوشهاى باستانشناسى، مطالعه 
Christie, M., Tsoflias, G. P., Stockli, D. F., \& Black, R. (2009). Assessing fault displacement and offfault deformation in an extensional tectonic setting using 3-D ground-penetrating radar imaging. Journal of applied geophysics, 68(1), 9-16.

Conyers L.B., Goodman, D. (2004). GroundPenitrating Radar, An Introduction for Archaeologists. Altaamira press. USA. pp. 232.

Daniels, D. J. (2004). Ground Penetrating Radar The Institution of Electrical Engineers. London, UK.

Davis, J. L., \& Annan, A. P. (1989). GroundPenetrating Radar for High-Resolution Mapping of Soil and Rock Stratigraphy1. Geophysical prospecting, 37(5), 531-551.

Denis, A., Huneau, F., Hœrlé, S., \& Salomon, A. (2009). GPR data processing for fractures and flakes detection in sandstone. Journal of Applied Geophysics, 68(2), 282-288.

Fischer, P. M., Follin, S. G., \& Ulriksen, P. (1980). Subsurface Interface Radar Survey at Hala Sultan Tekke, Cyprus. Swedish Annual Studies in Mediterranean Archaeology, 63, 48-64.

Giannopoulos, A. (2005). Modelling ground penetrating radar by GprMax. Construction and building materials, 19(10), 755-762.

Gondet, S., Dhemaied, A., Mohammadkhani, K., \& Rejiba, F. (2009). Geophysical investigations in the vicinity of the Persepolis Royal Terrace (Fars province, Iran). ArcheoSciences. Revue d'archéométrie, (33 (suppl.)), 69-72.

Goodman, D. (1994). Ground-penetrating radar simulation in engineering and archaeology. Geophysics, 59(2), 224-232.

Goodman, D., Piro, S., Schneider, K., Nishimura, Y., Hongo, H., Higashi, N., ... \& Damiata, B. (2009). GPR Archaeometry in GPR Theory and Applications, ed. H. Jol.

Gracia, V. P., Canas, J. A., Pujades, L. G., Clapés, J., Caselles, O., Garcia, F., \& Osorio, R. (2000). GPR survey to confirm the location of ancient structures under the Valencian Cathedral (Spain). Journal of Applied Geophysics, 43(2), 167-174.

Grandjean, G., Gourry, J. C., \& Bitri, A. (2000). Evaluation of GPR techniques for civilengineering applications: study on a test site. Journal of Applied Geophysics, 45(3), 141-156.

Irving, J., \& Knight, R. (2006). Numerical modeling of ground-penetrating radar in 2-D using MATLAB. Computers \& Geosciences, 32(9), 12471258.

Hagg, W., Mayer, C., Lambrecht, A., Kriegel, D., \& Azizov, E. (2013). Glacier changes in the big Naryn basin, central Tian Shan. Global and planetary change, 110, 40-50.

Jol, H.M. (2009). Ground Penitrating Radar: Theory and Applications. Oxford: Elsevier Science, 508 pages.

Knight, R. (2001). Ground penetrating radar for environmental applications. Annual Review of
Earth and Planetary Sciences, 29(1), 229-255.

Lin, M. C., Kang, Y. M., Lee, K. F., \& Hsu, H. C. (2009). A Study on the Technologies for Detecting Underground Water Level and Processing Image. International Journal of Applied Science and Engineering, 7(1), 61-68.

Martino, L., Bonomo, N., Lascano, E., Osella, A., \& Ratto, N. (2006). Electrical and GPR prospecting at Palo Blanco archaeological site, northwestern Argentina. Geophysics, 71(6), B193-B199.

Müller, K. (2005). Modelling of GPR Wave Propagation and Scattering in Inhomogeneous Media. phD. Thesis, Master Thesis in Geosciences Petroleum Geology and Geophysics Department of Geosciences University of Oslo.

Neal, A. (2004). Ground-penetrating radar and its use in sedimentology: principles, problems and progress. Earth-science reviews, 66(3), 261-330.

Negri, S., Leucci, G., \& Mazzone, F. (2008). High resolution 3D ERT to help GPR data interpretation for researching archaeological items in a geologically complex subsurface. Journal of Applied Geophysics, 65(3), 111-120.

Nobes, D. C. (1999). Geophysical surveys of burial sites: a case study of the Oaro urupa. Geophysics, 64(2), 357-367.

Olhoeft, G.R. (2001). GRORAD $A R^{T M}$, Acquisition, Processing, Modeling and Display of Dispersive Ground Penetrating Radar Data. version 2001.01.

Parasnis, D. S. (1997). Principles of applied geophysics. 5th edition, Chapman and Hall, Springer Netherlands Science - 429 pages.

Pauselli, C., Federico, C., Frigeri, A., Orosei, R., Barchi, M. R., \& Basile, G. (2010). Ground penetrating radar investigations to study active faults in the Norcia Basin (central Italy). Journal of applied geophysics, 72(1), 39-45.

Roberts, R. L., \& Daniels, J. J. (1997). Modeling near-field GPR in three dimensions using the FDTD method. Geophysics, 62(4), 1114-1126.

Radzevicius, S. J., Guy, E. D., \& Daniels, J. J. (2000). Pitfalls in GPR data interpretation: differentiating stratigraphy and buried objects from periodic antenna and target effects. Geophysical Research Letters, 27(20), 3393-3396.

Reynolds, J.M. (1997). An introduction to applied and environmental geophysics, John Wiley \& Sons Ltd. $\mathrm{UK}$.

Hubbard, S. S., \& Rubin, Y. (2005). Introduction to hydrogeophysics. In Hydrogeophysics (pp. 3-21). Springer Netherlands.

Shafri, H. Z. M., Abdullah, R. R., Roslee, M., \& Muniandy, R. (2008, July). Optimization of ground penetrating radar (GPR) mixture model in road pavement density data analysis. In IGARSS 2008-2008 IEEE International Geoscience and Remote Sensing Symposium (Vol. 3, pp. III1326). IEEE.

Sambuelli, L., Calzoni, C., Stocco, S., \& Rege, R. 
(2009, November). Geophysical measurements on the occasion of the moving of an ancient Egyptian sculpture. In Proceedings of the 28th GNGTS meeting, Trieste (pp. 16-19).

Singh, S. K., Rathore, B. P., Bahuguna, I. M., \& Ramnathan, A. L. (2012). Estimation of glacier ice thickness using Ground Penetrating Radar in the Himalayan region. Current Science(Bangalore), 103(1), 68-73.

Solla, M., Lorenzo, H., \& Riveiro, B. (2011). Evaluation of ancient structures by GPR: The arch bridges of Galicia (Spain). Scientific Research and Essays, 6(8), 1877-1884.

Sheets, P. D., Loker, W. M., Spetzler, H. A., \& Ware, R. W. (1985). Geophysical exploration for ancient Maya housing at Ceren, El Salvador. National Geographic Research Reports, 20, 645-656.

Shyeh, S. K., Nordiana, M. M., Anuar, S., Saad, R., \& Saidin, M. (2014). Archaeological Evidences Detection by using GPR Method: SB2K Site. EJGE, Bund. Y, 19: 8569-8578.

Teixeira, F. L., Chew, W. C., Straka, M., Oristaglio, M. L., \& Wang, T. (1998). Finite-difference timedomain simulation of ground penetrating radar on dispersive, inhomogeneous, and conductive soils. IEEE Transactions on Geoscience and remote sensing, 36(6), 1928-1937.

Van Dam, R. L., \& Schlager, W. (2000). Identifying causes of ground-penetrating radar reflections using time-domain reflectometry and sedimentological analyses. Sedimentology, 47(2), 435-449.

Vickers, R., Dolphin, L. T., \& Johnson, D. (1976). Archaeological investigations at Chaco Canyon using a subsurface radar. Remote Sensing Experiments in Cultural Resource Studies at Chaco Canyon. Albuquerque, New Mexico: USDI-NPS and the University of New Mexico, 81-101.

Weedon, W. H., \& Rappaport, C. M. (1997). A general method for FDTD modeling of wave propagation in arbitrary frequency-dispersive media. IEEE Transactions on Antennas and Propagation, 45(3), 401-410.

Yee, K. S. (1966). Numerical solution of initial boundary value problems involving Maxwell's equations in isotropic media. IEEE Trans. Antennas Propag, 14(3), 302-307.

Young, R. A., Deng, Z., \& Sun, J. (1995). Interactive processing of GPR data. The Leading Edge, 14(4), 275-280. 